\title{
Do Analysts and Investors Efficiently Respond to Managerial Linguistic Complexity on Conference Calls?
}

\begin{abstract}
This paper examines whether analysts and investors efficiently incorporate the informational cues from managerial linguistic complexity (e.g. Fog) on conference calls into their forecasts and trading decisions. We predict that managers use linguistic complexity to obfuscate before poor future earnings growth, but use linguistic complexity to provide informative disclosure before good future earnings growth. We find that the obfuscation (information) component of managerial Fog on a conference call is negatively (positively) associated with future earnings growth, and that the relations are generally stronger when there is a higher potential for earnings management during the period. We find that analyst forecast revisions efficiently respond to these informational signals in managerial Fog. However, while stock returns around the call are negatively associated with obfuscatory Fog, they are unrelated to informative Fog, which leads to a delayed positive return reaction to informative Fog after the call. Thus, while both analysts and investors appear to process the negative signal of managerial obfuscation, only analysts correctly interpret the positive signal of greater linguistic complexity due to more informative disclosure.
\end{abstract}




\section{INTRODUCTION}

Prior work finds that greater linguistic complexity (e.g., Fog) in corporate disclosures has a detrimental impact on sell-side analysts' ability to process the information in such disclosures (e.g., Lehavy, Li, and Merkley 2011; Bozanic and Thevenot 2015). Such complexity also dissuades some investors from actively responding to the disclosure (e.g., Miller 2010; Lundholm, Rogo, and Zhang 2014). Much of this work relies on "one-way" corporate disclosures like SEC filings and press releases. Interactive disclosures, like earnings conference calls, provide analysts the opportunity to ask questions to management, and for investors to listen to the discussion in real time. Mayew, Sharp, and Venkatachalam (2013) find that analysts participating in a call issue more accurate earnings forecasts, but they find limited evidence that such superior forecasting ability is due to information received during the call. Part of the challenge for analysts and investors is that managers may have incentives to obfuscate during calls to hide the companies' true performance.

Recent work by Bushee, Gow, and Taylor (2018) finds that, when managers use linguistic complexity to obfuscate, information asymmetry increases, whereas when they use complexity to provide more informative disclosure, there is a decrease in information asymmetry. While this evidence indicates that linguistic complexity affects the perceived informativeness of the call, it also suggests that managerial linguistic complexity could provide a signal of the manager's private information about expected future performance; i.e., managers use obfuscatory (informative) complexity when they expect poor (good) future performance. In this paper, we examine whether analysts and investors efficiently incorporate the informational cues from managerial linguistic complexity on conference calls into their decisions.

We also examine whether such cues are more important when there is greater uncertainty about earnings quality. Prior work finds that analysts have mixed success in assessing earnings quality when firms have potentially managed earnings; e.g., when firms have high discretionary 
accruals or just meet-or-beat forecasts (e.g., Bradshaw, Richardson, and Sloan 2001; Burghstahler and Eames 2003). In their survey of sell-side analysts, Brown, Call, Clement, and Sharp (2015) find the many analysts in interviews responded that "they exert little effort trying to determine whether firms misreport earnings" and the authors conclude that "sell-side analysts are unlikely to have incentives to try to uncover firm-specific financial misrepresentation" (p. 24). However, in contrast to the costs in time and effort of analyzing a 10-K to detect misreporting, it would be fairly low-cost for analysts (and investors) to use linguistic complexity cues on conference calls to infer whether managers are trying to obfuscate or to clarify the true nature of the company's performance. The benefits of such an analysis would certainly outweigh the costs when there is uncertainty about the quality of the earnings news. Thus, we test whether analysts and investors are more likely to respond to linguistic cues when there is potential earnings management.

We analyze a sample of almost 30,000 conference calls between 2006 and 2016. We measure the complexity of the language on the call using the Gunning (1952) Fog index. Following Bushee, et al. (2018), we use the Fog of analysts' questions during the call and a number of business complexity variables to decompose the Fog of the manager's language into an information component and an obfuscation component. The information component reflects the managers' disclosure response to business complexity in the absence of obfuscation (e.g., informative technical disclosure), whereas the obfuscation component reflects linguistic complexity intended to reduce the informativeness of the call. The information component is a fitted value whose variation largely stems from variation in the Fog of analysts language. We assume that managers wishing to provide more information content will engage with analysts, encouraging them to continue to ask complex questions, whereas managers wishing to provide less information will not engage, and analysts will ask less complex questions. This assumption is 
supported by Rennekamp, Sethuraman, and Steenhoven (2019), who find that greater engagement between analysts and managers on conference calls leads to more informative calls.

We test whether the linguistic cues provided by the information and obfuscation components of Fog are associated with future earnings growth, analysts' forecast revisions, and stock return reactions during and after the call. In each analysis, we control for the earnings surprise, other linguistic attributes of the manager's language (e.g., tone, forward-looking statements), the issuance of guidance, and firm fixed-effects. Thus, any significant results for the components of Fog can be interpreted as linguistic complexity providing an informative signal about manager's private information that is incremental to the current earnings news, other language features, and any inherent managerial linguistic style.

First, we hypothesize that the components of Fog provide a signal about future earnings growth. We find that the information component of Fog is positively associated with next year's earnings growth, while the obfuscation component is negatively associated with future earnings growth. This latter result confirms the Lee (2016) finding that "scripting" by managers to avoid answering questions is predictive of lower future earnings growth. We find that obfuscation Fog provides a similar negative signal, but we also find the new result that the manager's decision to provide informative disclosure through higher linguistic complexity is a positive signal about future earnings. In addition, we find that these relations are significantly stronger when there is a higher potential for earnings management (e.g., income-increasing accruals and just meet-or-beat target). Thus, managerial linguistic complexity provides an important signal of expected future earnings, especially when there is greater uncertainty about the quality of earnings.

Given these findings, we hypothesize that analysts will revise their forecasts of subsequent annual earnings downward when they perceive the manager is using high Fog to obfuscate. Similarly, when the manager uses high Fog to provide more informative disclosure, analysts 
should infer a positive signal about future earnings, leading to an upward revision in annual earnings forecasts. ${ }^{1}$ Consistent with our predictions, we find that the obfuscation (information) component of Fog is negatively (positively) associated with forecast revisions around the call. We also find that the Fog components have a stronger association with analyst forecast revisions when earnings quality is unclear. Thus, analysts efficiently use the informational cues in managerial Fog as an incremental signal of future earnings news when revising their forecasts of annual earnings.

We also hypothesize that investors listening to the call will pick up the informational cues in Fog, leading to a positive (negative) association between the information (obfuscation) component of Fog and three-day stock returns $(C A R)$ during the call window. We find that the $C A R$ is significantly negatively related to the obfuscation component, consistent with the Lee (2016) and Suslava (2017) findings of negative returns related to the use of scripting and euphemisms, respectively, to hide poor performance on calls. However, we do not find a significant association between $C A R$ and the information component. When we interact the Fog components with the indicators for potential earnings management, none of the interaction terms are significant, indicating that investors do not place more weight on linguistic complexity signals when there is potential earnings management. Thus, while both investors and analysts appear to process the cues in managerial obfuscation, only analysts correctly interpret the signal of greater linguistic complexity due to more informative disclosure.

The finding that investors do not immediately react to the positive signal of informative linguistic complexity raises the question of whether there is a delayed price reaction until investors get additional information (such as the updated analyst forecasts). We examine post-call stock returns (POST_CAR), defined as cumulative abnormal returns from two days after the conference

\footnotetext{
${ }^{1}$ While a more informative disclosure, in general, could produce good news or bad news, we expect to see more good news in this setting if managers strategically use linguistic complexity to provide more information when expected future earnings growth is positive, and to obfuscate when expected earnings growth is lower.
} 
call to the day after the next quarter's earnings announcement. We find that the obfuscation component is not significantly associated with POST_CAR, suggesting that investors completely impound the information in these signals in the conference call window. This finding is different from Lee (2016) and Suslava (2017), who both find delayed price reactions to scripting and euphemisms, respectively. Thus, the results suggest that obfuscating linguistic complexity is a clearer negative signal for investors than scripting and euphemisms.

We also find that POST_CAR is significantly positively associated with the information component, showing that there is a delayed price reaction to the positive signal in informative Fog. Moreover, the interactions between the Fog components and the indicators for potential earnings management are generally significant, consistent with investors under-reacting to the signals when earnings quality is uncertain. We find that these delayed reactions are triggered by the first analyst reports after the call window. Overall, these results indicate that investors immediately recognize linguistic complexity used to obfuscate, but do not immediately react to the positive signal of informative Fog or to the importance of the signals when there is potential earnings management. Analysts have a comparative advantage in reacting to these signals because they get to ask the questions, and can thus make an immediate assessment of whether the manager is trying to provide more information. Lacking this access, investors seem more uncertain about the implications of informative linguistic complexity, and do not fully react until after the call window when updated analyst forecasts becomes available.

In additional analyses, we find that, among managers who provide earnings guidance, managers providing more information on the call also provide more precise guidance, whereas managers obfuscating in their responses to analyst questions tend to provide less precise guidance. This finding suggests that managers act consistently across their guidance and call disclosure decisions in signaling future earnings. We also find that a higher information (obfuscation) 
component of Fog is associated with an improvement (reduction) in forecast accuracy and a reduction (improvement) in forecast dispersion. Thus, while analysts correctly interpret obfuscation as bad news, the lack of informative disclosure reduces the accuracy of the consensus forecast and leads to more disagreement among analysts. Finally, we find that short-term-oriented "transient" institutional investors increase (decrease) their holdings in response to higher information (obfuscation) components of Fog, whereas long-term-oriented investors (i.e., dedicated and quasi-indexer institutions) do not respond to linguistic complexity during the call. Thus, transient investors facilitate impounding the information in linguistic cues into price.

Our paper contributes to the literature by finding evidence that analysts not only correctly interpret the linguistic cues in Fog, but they rely more strongly on those cues when earnings management is more likely. Prior work finds that linguistic complexity has a detrimental impact on analyst forecasts and recommendations. We also find that investors immediately respond to Fog used to obfuscate, consistent with Lee (2016) and Suslava (2016), but unlike those papers, we do not find any delayed reaction to obfuscation Fog; investors appear to efficiently price this signal. Moreover, we find the new result that investors do not immediately respond to the positive signal in informative Fog, leading to a delayed price reaction. Thus, we conclude that analysts fulfill an important informational role by efficiently interpreting linguistic complexity into their forecasts.

\section{HYPOTHESES DEVELOPMENT AND RELATED RESEARCH}

\section{Linguistic Complexity as a Signal of Future Earnings}

Prior work finds that managers use linguistic complexity in disclosures to obfuscate the true nature of the firm's current and expected performance (see Loughran and McDonald 2016 for a review). Using the Gunning (1952) Fog Index to measure the linguistic complexity of 10-K filings, Li (2008) finds that firms with higher 10-K Fog have lower current earnings performance 
and less persistent future earnings performance. Lo, Ramos, and Rogo (2017) find that firms that are most likely to have managed earnings to beat the prior year's earnings have higher Fog in their MD\&As, suggesting that obfuscation incentives for linguistic complexity are especially high in earnings management years. Filzen and Peterson (2015) also show that firms with more complex financial statements are more likely to just beat analyst expectations.

However, recent work by Bushee, et al. (2018) suggests that linguistic complexity could be associated with more informative disclosure. Based on the assumption that analysts are unlikely to have obfuscation incentives when speaking during a conference call, Bushee, et al. (2018) use analyst linguistic complexity on the call to benchmark for the amount of linguistic complexity needed to understand the business. After decomposing managerial Fog on a conference call into a component that represents obfuscation and a component that represent informative technical disclosure, they find that the obfuscation (information) component of Fog is positively (negatively) associated with information asymmetry around the call.

As the fitted value in the decomposition model, the information component largely varies based on variation in the linguistic complexity of the analysts' language. Rennekamp, et al. (2019) use Linguistic Style Matching to measure the level of engagement between analysts and managers on calls. They find that greater engagement is associated with greater information content on the call. We rely on this finding to assume that managers wishing to provide more information content will engage with analysts, encouraging them to continue to ask complex questions, whereas managers wishing to provide less information will not engage, and analysts will ask less complex questions. Through this engagement mechanism, the Bushee, et al. (2018) information component measures the manager's choice to provide more information during the call.

Based on this prior work, we predict that a manager's linguistic complexity on a conference call provides a signal of the manager's private information about expected future earnings. Given 
that managers tend to obfuscate in the $10-\mathrm{K}$ when they report good earnings news that is transitory or bad earnings news that is persistent ( $\mathrm{Li} 2008$ ), we expect that managerial obfuscation during a conference call predicts lower earnings growth in the future. In contrast, Bushee, et al. (2018) finds that managers of some loss firms use linguistic complexity to provide more information. We expect that managers would be more likely to do so when they have bad earnings news that is expected to be transitory. Managers should also have incentives to be more informative about good earnings news that is expected to be persistent. Thus, we hypothesize the following:

H1: Future earnings growth following conference calls is negatively (positively) associated with obfuscating (informative) managerial linguistic complexity on the call.

\section{Linguistic Complexity and Analyst Forecast Revisions}

Prior work finds that linguistic complexity in a firm's disclosures affects the quality of analysts' forecast outputs. Lehavy, et al. (2011) show that higher Fog in 10-Ks is associated with greater dispersion, lower accuracy, and greater overall uncertainty in analyst earnings forecasts. Using earnings press releases, Bozanic and Thevenot (2015) find that higher readability in the form of shorter sentences, textual similarity, and lexical diversity are associated with decreases in analysts' uncertainty. Filzen and Peterson (2015) find that analysts rely more on management guidance and are more likely to exclude items from non-GAAP earnings forecasts for firms with more complex financial statements. Thus, this work suggests that greater linguistic complexity in written disclosures has a detrimental impact on analysts' ability to process information.

In contrast, prior work suggests that conference calls, in general, increase analysts' ability to forecast earnings accurately (Bowen, Davis, and Matsumoto 2002, Kimbrough 2005). Prior work also finds that analysts have incentives to acquire value-relevant information during conference calls (Mayew 2008; Matsumoto, Pronk, and Roelofsen 2011; Twedt and Rees 2012; Mayew, Sharp, and Venkatachalam 2013). Mayew, et al. (2013) find that analysts participating in 
a call issue more accurate earnings forecasts after the call than nonparticipating analysts. They find limited evidence that the superior forecasting ability is due to information received during the call, suggesting that the participating analysts' superior pre-call private information explains the results. Huang, Zang, and Rong (2014) find that analyst reports after conference calls are associated with a larger investor reaction when managers have incentives to withhold disclosure, but they do not look at whether the analysts' forecasts efficiently process the information in the call. Finally, consistent with analysts detecting managerial incentives to hide information on calls, Lee (2016) finds that the amount of "scripting" in managerial responses to questions on conference calls is negatively associated with future earnings performance and with analyst forecast revisions.

Based on the work suggesting that analysts efficiently process information in conference calls, we expect that analysts will efficiently process the informational cues in a manager's linguistic complexity on the call. If analysts correctly perceive that managers use high linguistic complexity to obfuscate expected poor future performance, then analysts will revise downward their forecasts of annual earnings. Similarly, if analysts correctly perceive that managers use high linguistic complexity to provide more informative technical disclosure about expected positive future performance, then analysts will revise upward revision their annual earnings forecasts based on this signal. Note that, with more informative disclosure, it is possible that analysts would learn bad news about the future and revise their forecasts downward. However, if we assume that, on average, managers with bad news have incentives to obfuscate, then informative disclosure should be more likely to be observed for good news. Thus, we hypothesize the following:

H2: Analyst forecast revisions following conference calls are negatively (positively) associated with obfuscating (informative) managerial linguistic complexity on the call. 


\section{Linguistic Complexity and Investor Reactions}

Prior work finds that investors immediately react to any new information released during conference calls, especially during the Q\&A portion (Bushee, Matsumoto, and Miller 2004; Matsumoto, Pronk, and Roelofsen 2011). Prior work also finds that investors react to linguistic cues during calls. Price et al. (2012) finds that the tone of the Q\&A part of the call is positively associated with the stock return reaction to the call, both during the three-day window and over the next two months. Hollander, Pronk, and Roelofsen (2010) show that when managers avoid answering specific questions during a call, there is a negative stock return reaction to the call. Lee (2016) finds that calls with more "scripted" managerial responses to questions have negative stock returns during the call window and over the subsequent quarter. Similarly, Suslava (2017) finds that the greater use of "euphemisms" to soften bad news is associated with negative stock returns during the call and over the next quarter. These findings suggest that investors will react negatively to obfuscating linguistic complexity during the call.

While Bushee, et al. (2018) find that the information component of linguistic complexity reduces information asymmetry, they do not test whether there is a positive return reaction to greater information. In general, more information could lead to either a greater positive or a greater negative return reaction depending on the nature of the information. However, if managers strategically provide more information when they expect higher earnings growth, then we expect such informative linguistic complexity to lead to a positive market reaction to the conference call. Thus, we hypothesize the following:

H3: Stock returns in the three-day window around conference calls are negatively (positively) associated with obfuscating (informative) managerial linguistic complexity on the call. 
Both the Lee (2016) and Suslava (2017) results suggest that, while investors do detect efforts to obfuscate during the call, they do not fully incorporate the information as there is a drift in negative returns after the call. Thus, we also examine whether investors efficiently react to the cues in linguistic complexity by testing whether the information or obfuscation components of linguistic complexity are associated with stock returns subsequent to the call. We do not provide any specific hypotheses for these tests; although based on prior work, we expect that any delayed reaction would be the result of under-reaction to the linguistic cues. Thus, subsequent returns would be negatively (positively) associated with obfuscating (informative) managerial linguistic complexity on the call.

\section{Interactive Effects of Linguistic Cues and Potential Earnings Management}

Prior work suggests that analysts have mixed success in detecting earnings management. Bradshaw, et al. (2001) find that analyst earnings forecasts do not incorporate the predictable future earnings declines associated with high abnormal accruals. Burghstahler and Eames (2003) find evidence that that analysts anticipate earnings management to avoid small losses and small earnings decreases, but that analysts often predict earnings management that is not realized (leading to forecast optimism at zero earnings forecasts) and fail to predict earnings management that is realized (leading to forecast pessimism at zero earnings realizations). Abarbanell and Lehavy (2003) conclude, "analysts either cannot anticipate or are not motivated to anticipate completely in their forecasts firms' efforts to manage earnings." In a survey of sell-side analysts, Brown, et al. (2015) report that analysts tend to not look for misreporting in the SEC filings, but they do try to determine whether the earnings are sustainable and reflect economic reality. ${ }^{2}$

\footnotetext{
${ }^{2}$ Coles, Hertzel, and Kalpathy (2006) find that, when earnings management is fairly transparent (e.g., abnormally low discretionary accruals between cancellations and reissuances of stock options), analysts are able to see through earnings management.
} 
Analysts and investors face a greater challenge in assessing the persistence of earnings news when the quality of earnings is more difficult to determine, such as when the earnings have a small cash component or when they are close to a target. In these cases, there is a higher probability that managers have manipulated earnings to meet a target, which means that analysts and investors have to assess the legitimacy of the current earnings news in addition to its implications for future earnings. On the other hand, Dechow, Richardson, and Tuna (2003) suggest that earnings that just meet-or-beat a target are not always an indicator of earnings management, as there are economic and regulatory reasons that could explain the discontinuity in earnings changes around zero. Similarly, high discretionary accruals could represent legitimate earnings if there is a change in the firm's economics in the given period. Thus, for firms with high discretionary accruals or that just meet-or-beat an earnings target, there is higher uncertainty about the quality of the earnings news (and the credibility of managers). Due to this uncertainty, managers likely have stronger incentives to obfuscate when they have managed earnings, and they have stronger incentives to provide more information when they have high-quality earnings that appear to be potentially managed. Consequently, we expect that any signal about obfuscation or informative disclosure present in high linguistic complexity will carry more weight for firms with uncertain earnings quality:

H4: The associations between linguistic complexity and future earnings, analyst forecast revisions, and stock return reactions are stronger when the potential for earnings management is high (e.g., income-increasing discretionary accruals, meet-or-beat earnings target).

\section{RESEARCH DESIGN}

\section{Informative versus Obfuscating Linguistic Complexity}

We develop measures for the obfuscation and information components of managerial linguistic complexity on conference calls following the approach of Bushee, et al. (2018). They 
use the linguistic complexity of analysts on the call, as well as a set of firm characteristics, to provide a benchmark for the level of complex language needed to understand the business. This expected level of managerial linguistic complexity is called the "information component;" i.e., the intrinsic amount of informative technical disclosure provided by managers on the conference call. The unexpected level of managerial linguistic complexity is called the "obfuscation component;" i.e., complex language that is likely intended to reduce the understandability of disclosure.

We construct our sample using conference call transcripts from SeekingAlpha.com; analyst and management forecasts from I/B/E/S; and stock returns and financial statement data from CRSP and Compustat. We begin the sample in 2006 when conference call transcripts become wellpopulated on SeekingAlpha.com and conclude in 2016. The sample consists of 71,648 firmquarters with conference call transcripts and the necessary CRSP, Compustat, and I/B/E/S data.

We measure linguistic complexity using the Gunning (1952) Fog index for the managerial presentation and the question and answer (Q\&A) portions of the call separately. The Fog index measures linguistic complexity as a function of the number of words per sentence and the percent of complex words, where complex words are those words with more than two syllables:

$\operatorname{Fog}()=.0.4 \times($ average number of words per sentence + percent of complex words $)(1)$

To provide a benchmark for the expected amount of linguistic complexity needed to understand the business, we estimate the following regression from Bushee, et al. (2018):

$$
\text { Fog }(\text { Manager })=\beta_{0}+\beta_{1} \text { Fog }(\text { Analyst })+\sum \beta_{\mathrm{i}} \text { Business Complexity Variables }+e(2)
$$

where Fog(Manager) is one of the two managerial Fog indexes, Fog(Present) or Fog(Response). Fog(Present) is the Fog of managers' language during the presentation portion of the call and Fog (Response) is Fog of the managers' responses in the Q\&A. Fog(Analyst) is the Fog of analysts' language during the Q\&A. The business complexity variables include market value of equity (Size); debt-to-assets ratio (Leverage); book-to-market ratio ( $B M)$; quarterly buy-and-hold stock returns 
(Returns); total acquisitions during the quarter (Acquisitions); PP\&E-to-assets ratio (CapIntensity); capital expenditures (Capex); research and development $(R \& D)$; debt and equity issuance (Financing); cash flow volatility ( $\sigma C F O)$; goodwill impairments (Goodwill); and restructuring charges (Restructuring) (Bushee, et al. 2018). All variables are defined in the Appendix.

The regression results for Equation (2) are reported in Panel A of Table 1. We rank all of the variables into deciles and scale them to range from 0 to 1 . The magnitude and significance of our coefficients are comparable with Bushee et al. (2018). Using these coefficients, we decompose managerial linguistic complexity into information and obfuscation components. The information components, Info(Present) and Info(Response), are measured as the fitted value from these coefficients in columns (1) and (2), respectively. These components capture managerial linguistic complexity that is driven by analyst linguistic complexity and business complexity. The obfuscation components, $O b f u($ Present) and $O b f u$ (Response), are measured as the residual value from the model in columns (1) and (2), respectively. These components capture managerial linguistic complexity uncorrelated with analyst complexity and business complexity.

Panel B of Table 1 reports descriptive statistics for our estimates of these components. The means of $O b f u($ Present) and $O b f u($ Response) are zero by construction because they are regression residuals. The standard deviation of Obfu(Present) (Obfu(Response)) is 1.455 (1.499). The mean Info(Present) is 16.116 and the mean Info(Response) is 12.708 ; the magnitude of these components is large because they include the intercept. Because Info(Present) and Info(Response) are highly correlated, we combine them into a single variable, Info(Both), using the first principle component of the two variables (Bushee, et al. 2018). As this analysis standardizes the variables, the mean of Info(Both) is zero. 


\section{Regressions for the Main Tests}

All of our main tests examine whether the components of managerial Fog provide a signal of manager's private information about expected future earnings using the following regression:

$$
\begin{gathered}
\left.D V=\beta_{0}+\beta_{1} \text { Obfu }(\text { Present })+\beta_{2} \text { Obfu(Response }\right)+\beta_{3} \text { Info }(\text { Both })+\beta_{\mathrm{i}} \text { CONTROLS }+ \text { Firm } \\
\text { Fixed Effects }+\varepsilon
\end{gathered}
$$

where $D V=G R O W T H_{t+1}, A F \_R E V, C A R, P O S T \_C A R$

For each $D V$, we expect $\beta_{1}$ and $\beta_{2}$ to be negative due to the hypothesized negative relation between obfuscation and expected future performance. We expect $\beta_{3}$ to be positive due to the hypothesized positive relation between informative disclosures and expected future performance.

We measure the dependent variables as follows. Next year's earnings growth, $G R O W T H_{t+1}$, is operating income from year $t+1$ minus operating income in year $t$, scaled by total assets in year $t$ and then multiplied by 100 (Lev and Nissim 2004; Huang et al. 2014). An analyst forecast revision, $A F \_R E V$, is defined the median analyst EPS forecast for year $t+1$ for all forecasts made within 30 days following the conference call (AFCpost) less the median consensus forecast of year $t+1$ directly before the conference call (AFCpre), divided by beginning-of-quarter price. ${ }^{3}$ The stock return reaction to the conference call, $C A R$, is the cumulative abnormal return for the threeday window $(-1,1)$ around the conference call. Finally, the post-conference call stock return, POST_CAR, is the cumulative abnormal return over the period beginning on Day +2 after quarter t's earnings announcement and ending on the Day +1 after the earnings announcement date for quarter $\mathrm{t}+1$. Abnormal returns are measured as the raw daily return from the CRSP minus the return on the portfolio of firms in the same size and book-to-market deciles.

\footnotetext{
${ }^{3}$ If there is more than one median consensus analyst forecast during the specified periods, AFCpre is the latest median consensus analyst forecast before the conference call date and AFCpost is the earliest median consensus analyst forecast after the conference call date.
} 
We control for a variety of firm characteristics throughout the analysis. First, we include the unexpected earnings surprise (UESURP) to measure the earnings news revealed in the earnings announcement. We define UESURP as the difference between actual EPS and the most recent median consensus analyst forecast prior to the call, scaled by beginning-of-quarter price (Kross, Ro, and Suk 2011; Kross and Suk 2012). We also include controls for firm size, growth, and performance, such as stock returns for the prior 12 months (RET), market value of equity (SIZE), book-to-market ratio $(B M)$, and earnings performance $(R O A)$. We control for analyst following $(A F N)$ and the level of institutional ownership (INST_OWN) as proxies for firms' external monitoring environment (Lang and Lundholm 1996; Kross, et al. 2011; Lehavy, et al. 2011). We also include a number of controls that are specific to certain regressions, such as the standard deviation of analyst forecasts prior to the conference call (AFSTD) (Ajinkya, Bhojraj, and Sengupta 2005), the lagged quarterly change in EPS from the prior year ( $\triangle L E P S)$ (Kross et al. 2011), return volatility prior to the call (RET_VOL), and return momentum prior to the call (RET_MOM) (Mayew and Venkatachalam 2012 and Lee 2016).

Finally, we include controls for a number of other textual attributes to ensure that our results reflect the effects of linguistic complexity. We measure the proportion of sentences containing forward-looking statements in the presentation and response parts of the call as FWDLOOK(Present) and FWDLOOK(Response), respectively (Li 2010 and Bozanic et al. 2018). We capture the tone of the call with the number of positive and negative words in the presentation and response parts of the call—POSTONE(Present), POSTONE(Response), NEGTONE(Present), NEGTONE(Response) — using the Loughran and McDonald (2011) dictionary. We also include an indicator variable that equals one if management guidance (GUIDANCE) is provided on the same day as the conference call; Billings, Jennings, and Lev (2015) report that over $80 \%$ of management forecasts are bundled with the earnings announcement in the post-Reg FD period. 
All regressions are estimated with firm fixed effects and all continuous variables are winsorized at $1 \%$ in either tail of the distribution to remove the effects of outliers. We adjust the standard errors by clustering observations by firm and by date of conference calls.

\section{Interactions with Indicators for Potential Earnings Management}

To test the interactive effects of linguistic complexity and potential earnings management, we estimate the following regressions:

$$
\begin{gathered}
\left.\left.\left.D V=\beta_{0}+\beta_{1} \text { Obfu(Present }\right)+\beta_{2} \text { Obfu (Response }\right)+\beta_{3} \text { Info }(\text { Both })+\beta_{4} \text { Obfu(Present }\right) \times E M \\
+\beta_{5} \text { Obfu }(\text { Response }) \times E M+\beta_{6} \text { Info }(\text { Both }) \times E M+\beta_{7} E M+\beta_{\mathrm{i}} \text { CONTROLS } \\
\text { Firm Fixed Effects }+\varepsilon
\end{gathered}
$$

where $D V=G R O W T H_{t+1}, A F \_R E V, \triangle I N S T \_O W N, C A R, P O S T \_C A R$

The variables of interest in this regression are the interactions Obfu(Present) $\times E M$, $O b f u$ (Response $) \times E M$, and $I n f o($ Both $) \times E M$, where $E M$ is one of the two proxies for potential earnings management: income-increasing discretionary accruals or meet-or-beat earnings. For all $\mathrm{DV}$, we expect $\beta_{4}$ and $\beta_{5}\left(\beta_{6}\right)$ to be negative (positive), capturing a stronger relation between obfuscating (informative) disclosure and expected future performance when the potential for earnings management is higher.

Our first proxy for potential earnings management uses discretionary accruals. We define income-increasing discretionary accruals, $I I \_D A=1$, if the firm reports discretionary accruals that are positive; otherwise $I I D D A=0$. Discretionary accruals are estimated using an annual crosssectional model for each industry defined at the two-digit SIC level, using the population of firms on Compustat (and requiring at least 10 observations in each industry-year group). ${ }^{4}$ Discretionary

\footnotetext{
${ }^{4}$ The annual period includes the quarter of the conference call, but we do not attempt to measure the amount of income-increasing discretionary accruals in that specific quarter's earnings. Quarterly discretionary accruals can be noisier than annual models (Jeter and Shivakumar 1999), so we are trading off measuring the exact timing of the income-increasing accruals during the year to get a more precise measurement of income-increasing accruals.
} 
accruals are calculated based on the Ball and Shivakumar (2006) model, including controlling for earnings performance Kothari, Leone, and Wasley (2005):

$$
A C=\alpha+\beta_{1} \Delta R+\beta_{2} P P E+\beta_{3} C F O+\beta_{4} D C F O+\beta_{5} C F O \times D C F O+\beta_{6} R O A+\varepsilon(5)
$$

where $A C$ is (cash flow from operations - income before extraordinary items)/average total assets; $\triangle R$ is $\left(\right.$ revenue $_{t}-$ revenue $\left._{t-1}\right) /$ average total assets; $P P E$ is gross property, plant, and equipment/average total assets; $C F O$ is cash flow from operations/average total assets; $D C F O$ is an indicator variable equal to one if $C F O$ is negative, and zero otherwise; and $R O A$ is (net income before extraordinary items)/average total assets. The residuals from this estimation form the discretionary accruals.

Our second proxy for potential earnings management is whether the firm just meet-or-beat its earnings target during the quarter (Burgstahler and Dichev 1997). We define the variable $M B E$ $=1$ if $\triangle E P S$ falls in the neighborhood from zero to three cents; otherwise $M B E=0$ (Lo, et al. 2017).

\section{EMPIRICAL RESULTS}

\section{Summary Statistics}

Table 2 presents summary statistics for the sample used in the main tests. From our sample of 71,648 conference calls with the necessary data to estimate the Fog decomposition model, we lose 39,291 observations when we require at least three analysts issuing forecasts. We lose additional 2,676 observations for missing data on control variables from CRSP and Compustat. These data requirements result in a sample of 29,664 firm-quarter observations for our main tests.

Table 2 shows that the mean (median) Obfu(Present) is $-0.0638(-0.0590)$ and the mean (median) Obfu(Response) is $-0.0709(-0.2368)$. The mean (median) Info(Both) is $0.0118(-0.0698)$. The mean (median) analyst forecast revision $\left(A F \_R E V\right)$ from before to after the conference call is $0.0003(0.0002)$. This suggests that, in general, analysts revise upward their forecasts of future 
earnings following the conference calls. For the additional two test variables proxying for potential earnings management, the mean $I I_{-} D A$ and $M B E$ are 0.386 and 0.107 , respectively. This suggests that about $39 \%$ of observations involve income-incoming discretionary accruals and $11 \%$ of them have just met or beat last year's earnings by a small amount.

\section{Linguistic Complexity and Future Earnings Growth}

We first examine whether a manager's linguistic complexity on a conference call provides a signal about future earnings (Hypothesis 1). Table 3 reports the main results based on equation (3) with next year's earnings growth as the dependent variable. Column (1) shows that Obfu(Present) and Obfu(Response) are both significantly negatively associated with next year's earnings growth, indicating that managerial obfuscation is more likely before low future earnings growth. In contrast, the coefficient on Info(Both) is positive and significant, indicating more informative linguistic complexity is associated with higher earnings growth in the next year. These results confirm Hypothesis 1 in showing that managers' decision to obfuscate or to inform through linguistic complexity provides a signal of next year's earnings growth.

In columns (2) and (3), we report regressions with interactions between the obfuscation and information components of Fog and the proxies for earnings management (equation (4)). We find that the coefficients on the interaction terms are all significant in the expected direction, showing the relation between the Fog components and future earnings growth is stronger when earnings management is more likely, consistent with Hypothesis 4. Overall, these results suggest that managers are more likely to obfuscate (provide information) before higher (lower) expected 
future earnings growth, indicating that linguistic complexity provides information about future earnings that is incremental to the earnings surprise and to other linguistic features, such as tone. ${ }^{5}$

\section{Analyst Forecast Revisions}

Next, we test whether analysts efficiently process the informational cues in a manager's linguistic complexity and revise their annual earnings forecasts accordingly. Table 4 reports the results from regressions of analyst forecast revisions on the obfuscation and information components of Fog and the control variables (equation (3)). Column (1) shows that the coefficients on $O b f u(P r e s e n t)$ and $O b f u(R e s p o n s e)$ are negative and significant, suggesting that analysts revise downward their forecasts of future earnings following calls with greater obfuscation. In contrast, the coefficient on Info(Both) is positive and significant, indicating that analysts revise upward their forecasts of future earnings when the linguistic complexity represents a greater amount of information. Thus, consistent with Hypothesis 2, analysts use the cues from linguistic complexity on the calls to update their forecasts negatively (positively) when managers are obfuscating (providing more information). ${ }^{6}$

Columns (2) and (3) provide tests of Hypothesis 4, in which we predict that the relation between linguistic complexity and forecast revisions will be stronger when there is a higher potential for earnings management. First, we note that there is no significant relation between

\footnotetext{
${ }^{5}$ We also estimate the regression in equation (7) using earnings growth in year $t+2$ and in year $t+3$ (not tabled). As expected, the associations between the Fog components and future earnings growth dissipate over longer horizons. For growth in year $\mathrm{t}+2$, the coefficients on Obfu(Present) and Info(Both) are both significant in the expected direction. For year $\mathrm{t}+3$, only $\mathrm{Obfu}$ (Present) is still significantly associated with earnings growth.

${ }^{6} \mathrm{We}$ also examine whether analyst forecast revisions are related to general linguistic complexity of managers. We find that the coefficient on Fog (Present) is negative and marginally significant ( $\mathrm{p}$-value $=0.053$ ), consistent with managerial obfuscation, on average, in the presentation part of the call. However, the coefficient on Fog (Response) in insignificant. These results suggest that analysts do not tend to react to the general level of linguistic complexity in revising their forecasts; rather, they differentiate between "good" and "bad" linguistic complexity.
} 
analyst forecast revisions and either $I I D A$ or $M B E .^{7}$ Thus, analysts do not systematically revise their forecasts downward (or upward) when there is potential earnings management. However, we find that the coefficients on the interactions between Obfu(Response) and both indicators for potential earnings management (II_DA and $M B E$, respectively) are negative and significant, consistent with Hypothesis 4. There is no significant interaction with Obfu(Present), suggesting that the analysts do not put more weight on obfuscation Fog in the presentation part of the call when earnings quality is unclear. The results also show that the coefficients on Info(Both) $\times E M$ are positive and significant in both the $I I D A$ and $M B E$ regressions, again consistent with Hypothesis 4. Overall, the results in Table 4 indicate that analysts efficiently incorporate the cues from managerial linguistic complexity during conference calls into their forecasts, and they place more weight on those cues when the potential for earnings management is higher.

\section{Stock Returns around the Conference Call}

Next, we examine whether market participants correctly interpret the informational cues in linguistic complexity when reacting to the information in the conference call. Table 5 presents the results of regressions of the 3-day cumulative abnormal returns $(C A R)$ around the conference call date on the obfuscation and information components of Fog and the control variables (equation (3)). To be consistent with prior work, we replace UESURP with the scaled decile rank, DSUE, and find the expected significant positive relation between the earnings surprise and $C A R$. We also find that a greater number of positive tone words in the manager's response (POSTONE(Response)) is positively associated with $C A R$, consistent with Price et al. (2012).

\footnotetext{
${ }^{7}$ If we drop the linguistic complexity variables from the regression, the coefficients on $I I D A$ and $M B E$ remain insignificant.
} 
Column (1) shows that the coefficients on Obfu(Present) and Obfu(Response) are both negative and significant, suggesting that investors correctly interpret obfuscation Fog in the presentation and the Q\&As as a negative signal about future earnings, consistent with Hypothesis 3. However, the coefficient on Info(Both) is not significant, indicating that investors do not react to the potential positive signal about future earnings in more informative linguistic complexity.

Columns (2) and (3) present results for the interactions with the potential earnings management indicators. Other than a marginally significant coefficient on $O b f u$ (Response) $\times E M$, none of the interaction terms are significant, while the coefficients on the main effects for Obfu(Present) and Obfu(Response) generally remain negative and significant, indicating that investors do not place more weight on linguistic complexity signals when there is potential earnings management. There is a negative and significant coefficient on $I I D A$, suggesting that investors view high discretionary accruals as less persistent earnings; this reaction actually subsumes the coefficient on Obfu(Response).

Thus, while both investors and analysts appear to process the cues in managerial obfuscation, only analysts correctly interpret the positive signal of greater linguistic complexity due to more informative technical disclosure. In addition, only analysts place a larger weight on linguistic cues when the potential for earnings management is high. These results suggest that analysts fulfill an important informational role in efficiently incorporating linguistic complexity into their forecasts.

\section{Post-call Stock Returns}

The finding that investors do not immediately react to the positive signal of informative linguistic complexity raises the question of whether there is a delayed price reaction. We examine post-call stock returns (POST_CAR), defined as cumulative abnormal returns from two days after 
the call to the day after the next quarter's earnings announcement. We estimate the regression in equation (3) using POST_CAR as the dependent variable and report the results in Table 6, Panel A. Column (1) shows that the coefficients on Obfu(Present) and Obfu(Response) are not significant, suggesting that investors completely impound the information in these signals in the conference call window. This finding differs from Lee (2016) and Suslava (2017), who both find delayed price reactions to scripting and euphemisms, respectively. Thus, the results suggest that obfuscating linguistic complexity is a clearer negative signal for investors than scripting and euphemisms.

Column (1) also shows the coefficient on Info(Both) is positive and significant. Thus, there is a delayed price reaction to the positive signal in informative linguistic complexity, consistent with investors missing the signal initially and then updating as more information, such as analyst forecast revisions, comes out after the call.

Columns (2) and (3) examine the interactions with potential earnings management. The coefficient on $O b f u($ Present) is negative and weakly significant in the regression with the high accruals interaction. Combined with Table 6, this result suggests that investors under-react to obfuscation for high accruals firms at the call date and update for the negative signal after the call. The coefficients on the Info(Both) interaction terms are positive and significant, consistent with the stronger positive signal about future earnings growth in informative linguistic complexity when there is a high potential for earnings management. Overall, these results indicate that investors do not efficiently process the positive signal of informative Fog at the time of the conference call, leading to a predictable delayed price reaction. 


\section{Stock Reactions to Analyst Forecasts Subsequent to the Call}

The finding that investors have a delayed price reaction to the positive signal in informative linguistic complexity raises the question of whether analysts play an information intermediary role in guiding investors following the conference calls. We next examine market reactions to the initial analyst forecast subsequent to the conference call (CAR_AnalystReport), defined as three-day cumulative abnormal returns surrounding the first report issued by analysts after the call window. We estimate the regression in equation (3) using CAR_AnalystReport as the dependent variable and report the results in Panel B of Table 6.

Column (1) shows that the coefficients on Obfu(Present) and Obfu(Response) are both insignificant, consistent with the Panel A results that investors fully incorporate the negative signal in obfuscation Fog during the call window. In contrast, the coefficient on Info(Both) is positive and significant, indicating a price reaction to information Fog when the first analyst reports are issued after the call window. Columns (2) and (3) show positive and marginally significant coefficients on Info $($ Both $) \times E M$ in both the $I I_{-} D A$ and $M B E$ regressions, consistent with analyst reports guiding investors to place more weight on information cues when earnings quality is unclear. Combined with Table 5 and Panel A of Table 6, these results suggest that investors initially do not react to the potential positive signals in managerial informative linguistic complexity at the call date, but realize the positive signal when analyst reports become available after the call. This delayed price reaction to informational cues, but not to obfuscation cues, suggests that obfuscation cues are easier for investors to detect at the conference call, whereas investors rely on analyst reports to clarify or confirm that the informational cues are indeed a positive signal about future earnings growth. 


\section{ADDITIONAL ANALYSES}

\section{Linguistic Complexity and Guidance}

We corroborate the results on the relations between linguistic complexity and future earnings growth (Table 3) by examining the relation between linguistic complexity and the characteristics of managerial guidance. To provide a signal of future earnings growth, managers have incentives to "guide through the Fog"; i.e., providing more information when it is more difficult for investors to capture the signal through complex 10-Ks (Guay, Samuels, Taylor 2016). Managers can do so by providing more frequent guidance or by providing more precise guidance (Cheng, Luo, and Yue 2013; Ettredge, Huang and Zhang 2013; Baginski and Hassell 1997). Because managers have great discretion in determining forecast characteristics, prior studies find that management forecast precision reflects managerial incentives to disclose their private information through guidance (Cheng et al. 2013). Thus, managers provide more precise guidance when they disclose (conceal) their private information about the future (Cheng et al. 2013).

We estimate the regression in equation (3) using managerial forecast precision as the dependent variable and report the results in Table 7. Following Ettredge et al. (2013) and Choi et al. 2010), management forecast precision is measured as the negative of the absolute value of the upper limit minus the lower limit, deflated by the share price at day -2 days, for range forecasts, or a dummy variable that equals 0 for annual earnings point forecasts. We find that Info(Both) is positively associated with management forecast precision, indicating that managers providing more information on the call also provide more precise guidance. We also find that Obfu(Present) is negative and significant, indicating that when managers are more likely to obfuscate in their responses to analyst questions, they tend to provide less precise guidance as well. This relation is 
stronger for firms that just meet-or-beat earnings targets. ${ }^{8}$ These findings suggest that managers act consistently across their guidance and call disclosure decisions in signaling future earnings.

\section{Analyst Forecast Accuracy and Dispersion}

While the primary focus of our paper is whether the informational cues in managerial linguistic complexity on conference calls provide a directional prediction about analyst forecast revisions, we also examine whether such cues improve accuracy and reduce dispersion in analyst forecasts. A greater amount of informative linguistic complexity on the call allows analysts to more precisely assess the persistence of the earnings shock, which should lead to improvements in forecast accuracy and reductions in forecast dispersion relative to calls with less informative disclosure. For linguistic complexity that represents obfuscation, it is possible that all analysts view obfuscation as a similarly negative signal about future earnings news, and hence become more accurate in their forecasts. However, prior work suggests that obfuscation is successful in creating uncertainty about the true nature of the news (Bushee, et al. 2018). If managerial obfuscation on the call leads analysts to put less weight on the new public information in the call and rely more on private information or on stale information, then the accuracy of their forecasts should decrease and dispersion should increase.

Table 7 reports the results from regressions of changes in analyst forecast accuracy and dispersion on the obfuscation and information components of Fog and the control variables (equation (3)). Panel A provides results for analyst forecast accuracy, define as the negative absolute value of analyst forecast errors (i.e., greater values indicate more accurate analyst forecasts). The change in analyst forecast accuracy around the call, $\triangle A F_{-} A C C R$, is measured as

\footnotetext{
${ }^{8} \mathrm{We}$ also examine the associations between a manager's linguistic complexity on the conference call and their forecast horizons and we find a similar but statistically weaker inference.
} 
[|Actual EPS - AFCpost//beginning-of-quarter price] - [|Actual EPS - AFCpre $/$ /beginning-ofquarter price], multiplied by -1 , where Actual EPS is the IBES actual and the analyst forecast variables are defined the same as in the forecast revision test (Kross and Suk 2012).

In column (1), the coefficient on Info(Both) is positive and significant, indicating that a higher information component of linguistic complexity is associated with an improvement in forecast accuracy. Thus, analysts not only use informative linguistic complexity as a signal of future good news, but also use the actual disclosure to improve the accuracy of their forecasts. The coefficient on $O b f u$ (Response) is negative and significant, suggesting that obfuscating linguistic complexity is associated with a decrease in the accuracy of the consensus forecast. Thus, while analysts correctly interpret obfuscation as bad news, the lack of informative disclosure, especially in the manager's responses to questions, reduces the accuracy of the consensus forecast.

In columns (2) and (3), we report the results with the interaction with potential earnings management indicators. None of the coefficients on the interactions between the potential earnings management indicators and Obfu(Present)/Obfu(Response) are significant, suggesting that obfuscation has a similar association on forecast accuracy regardless of earnings quality. However, the coefficients on the interactions between Info(Both) and both $I I_{-} D A$ and $M B E$ are positive and significant, indicating that the relation between the information component of linguistic complexity and forecast accuracy is strongly significant when the potential for earnings management is high.

Panel B provides results with changes in analyst forecast dispersion as the dependent variable. The change in analyst forecast dispersion, $\triangle A F \_D I S P$, is computed as ( $\mathrm{STD}(\mathrm{AFCpost})-$ $\operatorname{STD}(\mathrm{AFC} p r e)$ )/beginning-of-quarter price, where analyst forecast dispersion before (after) the call is the standard deviation of individual analysts' annual EPS forecasts for year $t+1$, issued during 
30 days before (after) the call. Similar to Kross and Suk (2012), we exclude observations if there are fewer than three analysts following a company for the 30-day period.

The results for changes in dispersion are similar to (and in some cases stronger than) the results for forecast accuracy. In column (1), the coefficients on Obfu(Present) and Obfu(Response) are positive and significant, suggesting that analyst forecast dispersion increases following the conference calls when there is more obfuscation in managers' presentations and Q\&As. In columns (2) and (3), we find that the association is generally stronger when the probability of earnings management is higher. Thus, managerial obfuscation leads analysts to put less weight on the public information in the call and more weight on their private information and on their personal assessments about the probability of misreporting, increasing the dispersion in their forecasts.

The coefficient on Info(Both) is negative and significant in column (1), indicating that analyst forecast dispersion declines following the calls with greater information components of linguistic complexity. In columns (2) and (3), the coefficients on Info(Both) $\times E M$ in both $I I D A$ and $M B E$ regressions are negative and significant, indicating that the relation between informative linguistic complexity and reductions in forecast dispersion are stronger when earnings management is more likely. Thus, informative complexity leads analysts to put more weight on the public information in the call, especially when there is uncertainty about earnings quality, reducing dispersion in forecasts.

\section{Changes in Institutional Ownership}

Finally, we examine whether institutional investors incorporate the informational cues in linguistic complexity into their trading decisions. Prior work finds that institutional investor ownership is positively associated with the readability of annual reports (Lundholm, Rogo, and Zhang 2014; Lang and Stice-Lawrence 2015). Guay, Samuels, and Taylor (2016) find the high 
(low) institutional ownership is associated with managers "guiding through the Fog"; i.e., providing more (less) voluntary disclosure when the 10-K has high linguistic complexity. This work suggests that institutional investors prefer less complex disclosure, in general. But, to the best of our knowledge, prior work has not looked at changes in institutional holdings in response to linguistic complexity, nor the Bushee, et al. (2018) decomposition of linguistic complexity into obfuscation and information components. We expect that, as sophisticated investors, institutional investors would efficiently react to the informational cues in linguistic complexity and tend to buy (sell) firms with higher information (obfuscation) Fog.

Table 8, Panel A, presents the results from regressions of changes in institutional ownership on the obfuscation and information components of Fog and the control variables (equation (3)). We measure the change in institutional investor ownership, $\triangle I N S T \_O W N$, as the difference between the percentage of institutional ownership at the beginning and end of the calendar quarter containing the conference call. Because institutional investor trading is not available within the quarter, it is challenging to identify whether the quarterly change in institutional holdings is reacting to the information in the conference call, per se, or to the analyst forecast revisions or stock return reactions to the call. Thus, we also include as controls the analyst forecast revision $\left(A F \_R E V\right)$ and the stock returns during and after the call (CAR and POST_CAR, respectively).

Column (1) shows that the change in institutional ownership is significantly positively associated with the analyst forecast revisions; stock returns during and after the call; the earnings surprise; and both forward-looking statements and positive tone words in the response. Controlling for these effects, there is some evidence that $\triangle I N S T \_O W N$ has a significantly negative incremental association with obfuscation Fog in the presentation (Obfu(Present)), and that this relation is 
stronger for firms that just meet-or-beat expectations. ${ }^{9}$ The coefficient on Info(Both) is positive and significant, indicating that institutional investors trade in response to the positive signal in informative linguistic complexity; however, institutions do not react more strongly when there is a higher potential for earnings management. These results suggest that institutional investors also react to the informational cues in linguistic complexity. However, given the lack of evidence for an immediate stock return reaction to informative Fog in Table 5, the results suggest that institutional investors likely do not react to informative Fog immediately, but rather only increase their holdings once they gather additional information (or once they realize that the positive signal has not yet been priced by the market). These findings are consistent with Bushee, Jung, and Miller (2011) who find that the institutional ownership increases with the number of the conference presentations the company makes, suggesting that the institutional investors gradually increase their ownership as they gather more information.

Since institutions have different investment horizons and information gathering capabilities, we further examine three different groups of institutional investors: transient, dedicated, and quasi-indexers, following the classification of Bushee (2001) and Bushee and Noe (2000). We expect that transient investors, who have a short-term focus, will be more likely to trade in response to informational cues in conference calls. As longer-term investors, dedicated and quasi-indexer investors should exhibit less sensitivity to linguistic complexity in earnings calls.

Column (1) of Panel B shows that changes in ownership by transient institutions are significantly negatively (positively) associated with obfuscation (information) Fog in managerial linguistic complexity in the conference call. Thus, transient institutions trade in response to the

\footnotetext{
${ }^{9}$ If we exclude $A F \_R E V$ from the regression, the coefficient on $O b f u$ (Response) is negative and significant, indicating that any association between institutional ownership and managerial obfuscation in the response is subsumed by including the analyst forecast revision.
} 
negative (positive) signals about future earnings growth in managerial linguistic complexity, consistent with their short-term-focused trading strategies (Bushee and Noe 2000).

Columns (2) and (3) show results for changes in ownership by dedicated and quasi-indexer institutions, respectively. We find that the changes in these two types of institutional ownership are unrelated to obfuscation or information Fog in the conference call. These findings indicate that dedicated and quasi-indexer institutions are likely indifferent to managerial information cues during the call because they are not frequent traders and the liquidity benefits of informative disclosure are less important to them than to transient institutions. ${ }^{10}$

\section{CONCLUSION}

Prior research suggests that managers use high linguistic complexity (i.e., Fog) in SEC filings to obfuscate poor performance. We find similar behavior in conference calls, as the obfuscation component of managerial Fog predicts lower future earnings growth. However, we also find new evidence that linguistic complexity used to provide more informative technical disclosure provides a positive signal of future earnings growth. We also find that these informational cues in linguistic complexity are stronger for firms with a higher potential for earnings management (e.g., income-increasing discretionary accruals and just meet-or-beat earnings targets), consistent with managers having stronger incentives to obfuscate poor performance and to inform about good performance when earnings quality is uncertain.

We find that analysts correctly interpret the negative (positive) signal about future performance in obfuscation (information) Fog and revise their forecasts downward (upward) accordingly. However, investors only correctly interpret the negative signal of obfuscation during

\footnotetext{
${ }^{10}$ Similar to the results for total institutional ownership, we find little evidence that the relations are stronger for firms with a higher probability of earnings management (untabulated).
} 
the call; stock returns during the call window are negatively associated with obfuscatory Fog, but unrelated to informative Fog. Consequently, we find a delayed price reaction, in which stock returns subsequent to the call are positively related to informative managerial Fog during the call, likely due to investors receiving analyst reports that correctly interpret the positive signal in informative Fog. Thus, analysts fulfill an important informational role by efficiently incorporating linguistic complexity during conference calls into their forecasts.

The advantage of the conference call setting is that we can control for the economic nature of the news (e.g., the earnings surprise) and other linguistic attributes to better isolate the role of linguistic complexity. There is also a low probability of reverse causality in our setting because it is unlikely that analysts intending to revise their forecasts downward would (or could) intentionally try to elicit obfuscatory linguistic complexity from managers. However, a caveat to our results is that it is difficult to conclusively establish causality between managers' linguistic choices and analysts' and investors' information processing in a conference call setting. Despite this, our results provide new evidence on the analyst and investor responses to linguistic complexity through exploiting the Bushee, et al. (2018) decomposition of linguistic complexity into its informative and obfuscatory components. These results suggest future research can increase the power of their tests examining textual attributes by using a similar decomposition. 


\section{References}

Abarbanell, J., and R. Lehavy. 2003. Can stock recommendations predict earnings management and analysts' earnings forecast errors? Journal of Accounting Research 41 (1): 1-31.

Ajinkya, B., S. Bhojraj, and P. Sengupta. 2005. The association between outside directors, institutional investors and the properties of management earnings forecasts Journal of Accounting Research 43 (3): 343-376.

Baginski, S. P., and J. M. Hassell. 1997. Determinants of management forecast precision. The Accounting Review 72 (2): 303-312.

Ball, R. A. Y., and L. Shivakumar. 2006. The role of accruals in asymmetrically timely gain and loss recognition. Journal of Accounting Research 44 (2): 207-242.

Billings, M. B., R. Jennings, and B. Lev. 2015. On guidance and volatility. Journal of Accounting and Economics 60 (2-3): 161-180.

Bowen, R. M., A. K. Davis, and D. A. Matsumoto. 2002. Do conference calls affect analysts' forecasts? The Accounting Review 77 (2): 285-316.

Bozanic, Z., and M. Thevenot. 2015. Qualitative disclosure and changes in sell-side financial analysts' information environment. Contemporary Accounting Research 32 (4): 1595-1616.

Bradshaw, M. T., S. A. Richardson, and R. G. Sloan. 2001. Do analysts and auditors use information in accruals? . Journal of Accounting Research 39 (1): 45-74.

Brown, L. D., A. C. Call, M. B. Clement, and N. Y. Sharp. 2015. Inside the "Black box" of sellside financial analysts. Journal of Accounting Research 53 (1): 1-47.

Burgstahler, D., and I. Dichev. 1997. Earnings management to avoid earnings decreases and losses. Journal of Accounting and Economics 24 (1): 99-126.

Burgstahler, D., and M. J. Eames. 2003. Earnings management to avoid losses and earnings decreases: Are analysts fooled? Contemporary Accounting Research 20 (2): 253-294.

Bushee, B. J. 2001. Do institutional investors prefer near-term earnings over long-run value? Contemporary Accounting Research 18 (2): 207-246.

Bushee, B. J., I. D. Gow, and D. J. Taylor. 2018. Linguistic complexity in firm disclosures obfuscation or information? Journal of Accounting Research 56 (1): 85-121.

Bushee, B. J., D. Matsumoto, and G. Miller. 2004. Managerial and investor responses to disclosure regulation: The case of Reg FD and conference calls. The Accounting Review 79: 617-643.

Bushee, B. J., and C. F. Noe. 2000. Corporate disclosure practices, institutional investors, and stock return volatility. Journal of Accounting Research 38 (Supplement): 171-202.

Cheng, Q., T. Luo, and Y. Yue. 2013. Managerial incentives and management forecast precision. The Accounting Review 88 (5): 1575-1602.

Choi, J., L. A. Myers, Y. Zang, and D. A. Ziebart. 2010. The roles that forecast surprises and forecast error play in determining management forecast precision. Accounting Horizons 24 (24): 165-188.

Coles, J. L., M. Hertzel, and S. Kalpathy. 2006. Earnings management around employee stock option reissues. Journal of Accounting and Economics 41 (1-2): 173-200.

Dechow, P. M., S. A. Richardson, and I. Tuna. 2003. Why are earnings kinky? An examination of the earnings management explanation. Review of Accounting Studies 8 (2-3): 355-384.

Ettredge, M., Y. Huang, and W. Zhang. 2013. Restatement disclosures and management earnings forecasts. Accounting Horizons 27 (2): 347-369.

Filzen, J. J., and K. Peterson. 2015. Financial statement complexity and meeting analysts' expectations. Contemporary Accounting Research 32 (4): 1560-1594. 
Guay, W., D. Samuels, and D. Taylor. 2016. Guiding through the Fog: Financial statement complexity and voluntary disclosure, Journal of Accounting and Economics 62: 234-269.

Gunning, R. 1952. The technique of clear writing. New York, NY: McGraw-Hill International Book Co.

Hollander, S., M. Pronk, and E. Roelofsen. 2010. Does silence speak? An empirical analysis of disclosure choices during conference calls, Journal of Accounting Research 48: 531-563.

Huang, A. H., A. Y. Zang, and Z. Rong. 2014. Evidence on the information content of text in analyst reports. The Accounting Review 89 (6): 2151-2180.

Jeter, D., and L. Shivakumar. 1999. Cross-sectional estimation of abnormal accruals using quarterly and annual data: Effectiveness in detecting event-specific earnings management. Accounting and Business Research 29 (4): 299-319.

Kimbrough, M. D. 2005. The effect of conference calls on analyst and market underreaction to earnings announcements. Accounting Review 80 (1): 189-219.

Kothari, S. P., A. J. Leone, and C. E. Wasley. 2005. Performance matched discretionary accrual measures. Journal of Accounting and Economics 39 (1): 163-197.

Kross, W. J., B. T. Ro, and I. Suk. 2011. Consistency in meeting or beating earnings expectations and management earnings forecasts. Journal of Accounting and Economics 51 (1-2): 3757.

Kross, W. J., and I. Suk. 2012. Does regulation fd work? Evidence from analysts' reliance on public disclosure. Journal of Accounting and Economics 53 (1-2): 225-248.

Lang, M. H., and R. J. Lundholm. 1996. Corporate disclosure policy and analyst behavior. Accounting Review 71 (4): 467-492.

Lang, M. H., L. Stice-Lawrence. 2015. Textual analysis and international financial reporting: Large sample evidence. Journal of Accounting and Economics 60: 110-135.

Lee, J. 2016. Can investors detect managers' lack of spontaneity? Adherence to predetermined scripts during earnings conference calls. Accounting Review 91 (1): 229-250.

Lehavy, R., L. Feng, and K. Merkley. 2011. The effect of annual report readability on analyst following and the properties of their earnings forecasts. Accounting Review 86 (3): 10871115.

Lev, B., and D. Nissim. 2004. Taxable income, future earnings, and equity values. The Accounting Review 79 (4): 1039-1074.

Li, F. 2008. Annual report readability, current earnings, and earnings persistence. Journal of Accounting and Economics 45 (2-3): 221-247.

Lo, K., F. Ramos, and R. Rogo. 2017. Earnings management and annual report readability. Journal of Accounting and Economics 63 (1): 1-25.

Loughran, T., and B. McDonald. 2011. When is a liability not a liability? Textual analysis, dictionaries, and 10 - Ks, The Journal of Finance 66 (1): 35-65.

Loughran, T., and B. McDonald. 2016. Textual analysis in accounting and finance: A survey. Journal of Accounting Research 54 (4): 1187-1230.

Lundholm, R., R. Rogo, and J. Zhang. 2014. Restoring the Tower of Babel: How foreign firms communicate with U.S. investors. The Accounting Review 89: 1453-1485.

Matsumoto, D., M. Pronk, and E. Roelofsen. 2011. What makes conference calls useful? The information content of managers' presentations and analysts' discussion sessions. The Accounting Review 86 (4): 1383-1414.

Mayew, W. J. 2008. Evidence of management discrimination among analysts during earnings conference calls. Journal of Accounting Research 46 (3): 627-659. 
Mayew, W. J., and M. Venkatachalam. 2012. The power of voice: Managerial affective states and future firm performance. The Journal of Finance 67 (1): 1-44.

Mayew, W. J., N. Y. Sharp, and M. Venkatachalam. 2013. Using earnings conference calls to identify analysts with superior private information. Review of Accounting Studies 18 (2): 386-413.

Miller, B. P. 2010. The effects of reporting complexity on small and large investor trading. The Accounting Review 85: 2107-2143.

Price, S. M., J. Doran, D. Peterson, and B. Bliss. 2012. Earnings conference calls and stock returns: The incremental informativeness of textual tone. Journal of Banking \& Finance 36: $992-$ 1011.

Rennekamp, K., M. Sethuraman, and B. Steenhoven. 2019. Engagement in Earnings Conference Calls: A Multi-Method Examination. Working Paper, Cornell University.

Suslava, K. 2017. Stiff business headwinds and unchartered economic waters: The use of euphemisms in earnings conference calls. Working paper, Rutgers Newark and New Brunswick.

Twedt, B., and L. Rees. 2012. Reading between the lines: An empirical examination of qualitative attributes of financial analysts' reports. Journal of Accounting and Public Policy 31: 1-21. 


\section{APPENDIX \\ Variable Definitions}

\begin{tabular}{|c|c|}
\hline Variable & Definition \\
\hline \multicolumn{2}{|c|}{ Measures of linguistic complexity } \\
\hline Fog(.) & $\begin{array}{l}=\text { Fog index of the respective portion of the conference call. Fog(Analyst) refers to the } \\
\text { Fog index of analysts during the call. Fog(Present) refers to the Fog index of } \\
\text { managers during the presentation portion of the call. Fog(Response) refers to the Fog } \\
\text { index of managers' during the response portion of the call. }\end{array}$ \\
\hline Obfu(.) & $\begin{array}{l}=\text { Estimated latent obfuscation component following Bushee, Gow, and Taylor (2018). } \\
\text { Obfu(Present) refers to the presentation portion of the call, and Obfu(Response) } \\
\text { refers to the response portion of the call. }\end{array}$ \\
\hline Info(.) & $\begin{array}{l}=\text { Estimated latent information component following Bushee, Gow, and Taylor (2018). } \\
\text { Info(Present) refers to the presentation portion of the call, and Info(Response) refers } \\
\text { to the response portion of the call. Info(call) refers to the first principal component of } \\
\text { Info(Present) and Info(Response). }\end{array}$ \\
\hline \multicolumn{2}{|c|}{ Firm characteristics to estimate linguistic complexity } \\
\hline Acquisitions & $\begin{array}{l}=\text { Total acquisitions during the quarter, scaled by total assets at the beginning of the } \\
\text { quarter. }\end{array}$ \\
\hline$B M$ & $=$ Book value of equity scaled by market value of equity at the beginning of the quarter. \\
\hline Capex & $=$ Amount of capital expenditures scaled by total assets at the beginning of the quarter. \\
\hline CapIntensity & $\begin{array}{l}=\text { Net plant, property, and equipment scaled, scaled by total assets at the beginning of } \\
\text { the quarter. }\end{array}$ \\
\hline Financing & $\begin{array}{l}=\text { Amount raised from stock and debt issuances during the quarter scaled by total assets } \\
\text { at the beginning of the quarter. }\end{array}$ \\
\hline Goodwill & $=$ Indicator variable for whether the firm had a goodwill impairment charge that quarter \\
\hline Leverage & $\begin{array}{l}=\text { Long-term debt plus short-term debt, scaled by total assets at the beginning of the } \\
\text { quarter. }\end{array}$ \\
\hline$R \& D$ & $=$ Ratio of research and development expense to sales. \\
\hline Restructuring & $=$ Indicator variable for whether the firm had a restructuring charge that quarter \\
\hline Returns & $=$ Buy-and-hold return over the quarter, in percent. \\
\hline Size & $=$ Natural $\log$ of market value of equity at the beginning of the quarter. \\
\hline$\sigma C F O$ & $\begin{array}{l}=\text { Standard deviation of cash flows from operations scaled by total assets at over the } \\
\text { prior five years. }\end{array}$ \\
\hline
\end{tabular}


Dependent Variables

$\boldsymbol{G R O W T H}_{t+1} \quad=$ Future earnings growth, measured as operating income from year $t+1$ minus operating income in year $t$, scaled by total assets in year $t$ and then multiply by 100 , following Huang et al. (2014).

AF_REV

$=$ Analyst forecast revision, computed as (AFCpost $-\mathrm{AFCpre}$ )/beginning-of quarter price. It is measured as the difference between the median of analyst forecasts for year $t+1$ earnings, issued within 30 days post to the conference call (AFCpost), and the median of analyst forecasts for year $t+1$ earnings, issued within 30 days prior to the conference call (AFCpre), and then the difference is scaled by price at the beginning of the fiscal quarter. If analysts made more than one median consensus analyst forecast during the specified period above, we use the one closest to the conference call date in calculating AFCpost and AFCpre.

$\boldsymbol{C A R} \quad=$ The three-day $(-1,1)$ cumulative abnormal return around the conference call disclosure date. Abnormal returns are measured as the raw return from CRSP minus the return on the portfolio of firms with approximately the same size (the market value of equity as of December) and book-to-market (BM) ratio (as of the prior June).

CAR_AnalystReport = The three-day $(-1,1)$ cumulative market-adjusted abnormal return around the first analyst report issued subsequent to the conference call window. Day 0 is the day when the first analyst forecast following the conference call is issued.

MGMT_PRECISION = An indicator variable that equals the negative of (the absolute value of [the upper limit minus the lower limit] deflated by the share price at day-2 day for range forecasts, or zero for annual earnings point forecasts. A larger coefficient is associated with more precise forecasts.

POST_CAR

$=$ The cumulative daily abnormal return over the period beginning on Day +2 after quarter $t$ 's earnings announcement and ending on the Day +1 after the earnings announcement date for quarter $t+1$.

$\triangle A F \_A C R$

$=$ Change in analyst forecast accuracy, defined as the difference in negative absolute value of analyst forecast errors. It is measured by (ABS(Actual EPS -AFCpost)/beginning-of quarter price) - (ABS(Actual AFCpre)/beginning-of quarter price) $\}^{*}(-1)$, where AFCpost (AFCpre is the median consensus analyst forecast issued within 30 days after (before) the managers' conference calls and Actual EPS is the IBES actual. We multiply the result by -1 such that greater values indicate more accurate forecasts.

$\Delta A F \_D I S P$

$=$ Change in analyst forecast dispersion, defined as the difference in standard deviation of analyst annual earnings forecasts. It is measured by (STD(AFCpost) - STD(AFCpre))/beginning-of quarter price, where AFCpost (AFCpre) is the standard deviation of individual analyst forecasts issued within 30 days after (before) the managers' conference calls.

AINST_OWN
$=$ The change in percentage of institutional ownership from the end of calendar quarter prior to the conference call to the end of quarter $t+1$. 


\begin{tabular}{|c|c|c|}
\hline II_DA & $=$ & $\begin{array}{l}\text { An indicator variable that equals one if the annual discretionary accruals are } \\
\text { income increasing. Discretionary accruals are estimated using the cross- } \\
\text { sectional (Ball and Shivakumar 2006) model and controlling for firm } \\
\text { performance following (Kothari et al. 2005), estimated by industry and } \\
\text { year. Specifically, discretionary accruals are estimated as the residual from } \\
\text { the regression: AC }=\alpha+\beta 1 \Delta \mathrm{R}+\beta 2 \mathrm{PPE}+\beta 3 \mathrm{CFO}+\beta 4 \mathrm{DCFO}+\beta 5 \mathrm{CFO} \times \\
\mathrm{DCFO}+\beta 6 \mathrm{ROA}+\varepsilon \text {. AC is (cash flow from operations }- \text { income before } \\
\text { extraordinary items)/average total assets; } \Delta \mathrm{R} \text { is (revenuet }- \text { revenuet- } \\
1 \text { /average total assets; PPE is gross property, plant, and equipment/average } \\
\text { total assets; CFO is cash flow from operations/average total assets; DCFO } \\
\text { is an indicator variable equal to one if CFO is negative, and zero otherwise; } \\
\text { and ROA is (net income before extraordinary items)/average total assets. }\end{array}$ \\
\hline$M B E$ & $=$ & $\begin{array}{l}\text { An indicator variable that equals one if } \triangle E P S(E P S q-E P S q-4) \text { falls in the } \\
\text { neighborhood from zero to three cents; } 0 \text { otherwise. }\end{array}$ \\
\hline UESURP & $=$ & $\begin{array}{l}\text { The difference between Actual earnings and the most recent median } \\
\text { consensus analyst forecast prior to the conference call date, scaled by the } \\
\text { price at the beginning of the fiscal quarter. }\end{array}$ \\
\hline AFSTD & $=$ & $\begin{array}{l}\text { The standard deviation of analyst forecasts in the fiscal quarter prior to the } \\
\text { conference call disclosure, scaled by price at the beginning of the fiscal } \\
\text { quarter. }\end{array}$ \\
\hline$\triangle L E P S$ & & $\begin{array}{l}\text { The change in earnings per share at the beginning of the quarter (EPSq- } 1- \\
\text { EPSq-5) prior to the conference call disclosure, scaled by q- } 5 \text { quarter price. }\end{array}$ \\
\hline RET & $=$ & $\begin{array}{l}\text { Market-adjusted (value-weighted) buy-and-hold returns for the previous } 12 \\
\text { months prior to the conference call disclosure. }\end{array}$ \\
\hline RET VOL & $=$ & $\begin{array}{l}\text { Stock return volatility, measured as the standard deviation of daily stock } \\
\text { returns over the period }[-127,-2] \text { relative to the conference call date, } \\
\text { following Mayew and Venkatachalam (2012). }\end{array}$ \\
\hline RET MOM & $=$ & $\begin{array}{l}\text { The buy-and-hold return over the window }[-127,-2] \text { before the conference } \\
\text { call date, following Mayew and Venkatachalam (2012). }\end{array}$ \\
\hline$S I Z E$ & $=$ & $\begin{array}{l}\text { Natural log of market value of equity at the beginning of the fiscal quarter, } \\
\text { prior to the conference call disclosure. }\end{array}$ \\
\hline$L M B$ & $=$ & $\begin{array}{l}\text { Natural log of market-to-book ratio at beginning of the fiscal quarter, prior } \\
\text { to the conference call disclosure. }\end{array}$ \\
\hline$A F N$ & $=$ & $\begin{array}{l}\text { The number of analysts following at the end of the fiscal quarter, prior to } \\
\text { the conference call disclosure. }\end{array}$ \\
\hline INST_OWN & $=$ & $\begin{array}{l}\text { The percentage of institutional ownership at the beginning of the fiscal year } \\
\text { end, prior to the conference call disclosure. }\end{array}$ \\
\hline $\boldsymbol{R O A}$ & $=$ & $\begin{array}{l}\text { An indicator variable that equals one if ROA in year } t \text { is negative; } 0 \\
\text { otherwise. }\end{array}$ \\
\hline LOSS & $=$ & An indicator variable that equals one if ROA in year $t$ is negative. \\
\hline DSUE & $=$ & $\begin{array}{l}\text { The decile of earnings surprise, which is defined as the actual EPS minus } \\
\text { the most recent consensus analyst forecast, scaled by the price at the } \\
\text { beginning of the fiscal quarter. The coefficient of DSUE can be interpreted } \\
\text { as the abnormal return earned on a zero-investment portfolio that takes a } \\
\text { long position in the highest DSUE decile (DSUE }=1 \text { ) and a short position in } \\
\text { the lowest DSUE decile (DSUE }=0 \text { ). }\end{array}$ \\
\hline
\end{tabular}


SPECIAL

4thQTR

RESPONSIVE

BNEWS

EP Ratio

FWDLOOK(Present)

POSTONE(Present) $=$ The number of positive tone words in the presentation of the call.

POSTONE(Response) $=$ The number of positive tone words in the response of the call.

NEGTONE(Present) = The number of negative tone words in the presentation of the call.

NEGTONE(Response) = The number of negative tone words in the response of the call.

GUIDANCE
$=$ An indicator variable that equals one if firm $i$ reports negative special items in quarter $t ; 0$ otherwise.

$=$ An indicator variable that equals one if the earnings announcement is for the fourth fiscal quarter; 0 otherwise.

$=$ An indicator variable that equals one if there is at least one analyst revising the forecast of next year's earnings within two trading days after the current quarter earnings announcement; 0 otherwise.

$=$ An indicator variable that equals one if the unexpected earnings are negative; 0 otherwise.

$=$ Basic earnings per share (excluding extraordinary items) scaled by price at the beginning of the fiscal quarter.

$=$ The proportion of sentences containing forward-looking statements in the presentation of the call. We classify sentences in the call as forward-looking sentences if they include at least one forward-looking term, following $\mathrm{Li}$

$=$ An indicator variable that equals one if at least one quantitative guidance is provided on the same day as the conference call, based on the IBES Guidance database. (2010) and Bozanic et al. (2018). 


\section{Table 1}

\section{Estimating the Latent Components of Managers' Linguistic Complexity}

\begin{tabular}{|c|c|c|c|c|}
\hline \multirow{2}{*}{$\begin{array}{l}\text { Dependent Variable } \\
\text { Variable } \\
\text { Fog(Analyst) }\end{array}$} & \multicolumn{2}{|l|}{$\begin{array}{c}\text { Fog (Present) } \\
(1)\end{array}$} & \multicolumn{2}{|c|}{$\begin{array}{c}\text { Fog (Response) } \\
(2) \\
\end{array}$} \\
\hline & $\begin{array}{r}0.085 \\
(21.89)\end{array}$ & $* * *$ & $\begin{array}{r}0.341 \\
(62.35)\end{array}$ & $* * *$ \\
\hline Size & $\begin{array}{r}-0.974 \\
(-13.24)\end{array}$ & $* * *$ & $\begin{array}{l}-0.010 \\
(-0.45)\end{array}$ & \\
\hline Leverage & $\begin{array}{r}0.349 \\
(4.93)\end{array}$ & $* * *$ & $\begin{array}{r}0.148 \\
(4.77)\end{array}$ & $* * *$ \\
\hline$B M$ & $\begin{array}{l}-0.092 \\
(-1.21)\end{array}$ & & $\begin{array}{l}-0.287 \\
(-6.65)\end{array}$ & $* * *$ \\
\hline Returns & $\begin{array}{l}-0.163 \\
(-7.59)\end{array}$ & $* * *$ & $\begin{array}{l}-0.037 \\
(-3.82)\end{array}$ & $* * *$ \\
\hline Acquisitions & $\begin{array}{l}-0.305 \\
(-5.69)\end{array}$ & $* * *$ & $\begin{array}{l}-0.059 \\
(-2.09)\end{array}$ & $*$ \\
\hline CapIntensity & $\begin{array}{l}-0.490 \\
(-5.67)\end{array}$ & $* * *$ & $\begin{array}{r}-0.619 \\
(-18.32)\end{array}$ & $* * *$ \\
\hline Capex & $\begin{array}{l}0.001 \\
(0.02)\end{array}$ & & $\begin{array}{l}0.132 \\
(2.36)\end{array}$ & $* *$ \\
\hline$R \& D$ & $\begin{array}{l}0.369 \\
(4.46)\end{array}$ & $* * *$ & $\begin{array}{l}0.420 \\
(8.44)\end{array}$ & $* * *$ \\
\hline Financing & $\begin{array}{l}0.133 \\
(1.72)\end{array}$ & $*$ & $\begin{array}{l}0.030 \\
(1.15)\end{array}$ & \\
\hline$\sigma C F O$ & $\begin{array}{l}-0.295 \\
(-6.48)\end{array}$ & $* * *$ & $\begin{array}{r}-0.354 \\
(-7.6)\end{array}$ & $* * *$ \\
\hline Goodwill & $\begin{array}{l}0.232 \\
(2.97)\end{array}$ & $* * *$ & $\begin{array}{l}0.076 \\
(2.55)\end{array}$ & $* *$ \\
\hline Restructing & $\begin{array}{l}-0.066 \\
(-0.99)\end{array}$ & & $\begin{array}{l}0.062 \\
(4.56)\end{array}$ & $* * *$ \\
\hline $\begin{array}{l}\text { No.Obs. } \\
\text { Adj R2 }\end{array}$ & $\begin{array}{r}71,648 \\
7.324 \%\end{array}$ & & $\begin{array}{r}71,648 \\
20.51 \%\end{array}$ & \\
\hline
\end{tabular}


Table 1

Estimating the Latent Components of Managers' Linguistic Complexity

\begin{tabular}{|c|c|c|c|c|c|}
\hline Variable & Mean & Std & P25 & Median & P75 \\
\hline Obfu(Present) & 0.000 & 1.455 & -0.925 & 0.009 & 0.959 \\
\hline Obfu(Response) & 0.000 & 1.499 & -1.047 & -0.146 & 0.907 \\
\hline Info(Present) & 16.116 & 0.409 & 15.821 & 16.095 & 16.397 \\
\hline Info(Response) & 12.708 & 0.761 & 12.190 & 12.628 & 13.125 \\
\hline Info $($ Both $)$ & 0.000 & 0.800 & -0.546 & -0.083 & 0.440 \\
\hline
\end{tabular}

Table 1 presents the regression results and descriptive statistics of the latent components of the linguistic complexity. Panel A reports results from estimating the linguistic complexity of managers during the respective portion of the conference call, Fog (Present) and Fog (Response), as a function of the linguistic complexity of analysts, Fog(Analyst), and variables related to business complexity. We use the following variables to measure business complexity: firm size (Size); firm leverage (Leverage); book-to-market ratio (BM); historical stock performance (Returns); acquisitions (Acquisitions), capital intensity (CapIntensity), capital expenditures (Capex), research and development (R\&D); debt and equity issuance (Financing); cash flow volatility $(\sigma C F O)$; goodwill impairments (Goodwill) and restructuring charges (Restructuring). See Appendix for variable definitions. For ease of interpretation, each of the variables is ranked into deciles and scaled to range from 0 to 1 . $t$-statistics appear in parentheses and are based on standard errors clustered by firm and disclosure date of the conference call. ***,**, and * denote statistical significance at the 0.01 , 0.05 , and 0.10 levels (two-tail), respectively. Panel B reports the distribution of our empirical estimates of the latent components of managers' linguistic complexity. $O b f u($.$) is the latent obfuscation component during the respective$ section of the call and Info(.) is the latent information component during the respective section of the call. Info(Both) is the first principal component of Info(Present) and Info(Response). 
Table 2

Descriptive Statistics

\begin{tabular}{|c|c|c|c|c|c|c|}
\hline Variables & $\mathbf{N}$ & Mean & Std & P25 & Median & P75 \\
\hline Obfu(Present) & 29,664 & -0.0638 & 1.4335 & -0.9781 & -0.0590 & 0.8822 \\
\hline Obfu(Response) & 29,664 & -0.0709 & 1.4373 & -1.0897 & -0.2368 & 0.7876 \\
\hline Info(Both) & 29,664 & 0.0118 & 0.7390 & -0.4879 & -0.0698 & 0.4198 \\
\hline GROWTHt +1 & 28,391 & 0.5002 & 5.8154 & -1.1518 & 0.5227 & 2.2628 \\
\hline$A F \_R E V$ & 29,664 & 0.0003 & 0.0147 & -0.0014 & 0.0002 & 0.0031 \\
\hline AINST_OWN & 27,644 & 0.0008 & 0.0997 & -0.0398 & 0.0055 & 0.0540 \\
\hline$C A R$ & 29,664 & 0.0016 & 0.0734 & -0.0342 & 0.0011 & 0.0390 \\
\hline POST_CAR & 29,225 & 0.0031 & 0.1487 & -0.0780 & 0.0053 & 0.0861 \\
\hline$\triangle A F_{-} A C C R$ & 29,656 & 0.0000 & 0.0118 & -0.0014 & 0.0002 & 0.0022 \\
\hline$\Delta A F_{-} D I S P$ & 21,224 & 0.0022 & 0.1280 & -0.0358 & -0.0024 & 0.0333 \\
\hline$I I \_D A$ & 29,664 & 0.3863 & 0.4869 & 0.0000 & 0.0000 & 1.0000 \\
\hline$M B E$ & 29,664 & 0.1067 & 0.3088 & 0.0000 & 0.0000 & 0.0000 \\
\hline UESURP & 29,664 & -0.0026 & 0.0296 & -0.0037 & 0.0003 & 0.0035 \\
\hline AFSTD & 29,664 & 0.0076 & 0.0165 & 0.0012 & 0.0030 & 0.0071 \\
\hline$\triangle L E P S$ & 29,664 & 0.0013 & 0.0159 & -0.0021 & 0.0012 & 0.0041 \\
\hline$R E T$ & 29,664 & 0.0496 & 0.3646 & -0.1581 & 0.0062 & 0.1903 \\
\hline SIZE & 29,664 & 8.1858 & 1.6298 & 7.0426 & 8.1700 & 9.2831 \\
\hline$B M$ & 29,664 & 0.4680 & 0.2582 & 0.2500 & 0.4500 & 0.6800 \\
\hline$A F N$ & 29,664 & 21.019 & 16.271 & 9.0000 & 17.000 & 28.000 \\
\hline INST_OWN & 29,664 & 0.7628 & 0.2080 & 0.6623 & 0.7992 & 0.9003 \\
\hline$R E T \_V O L$ & 29,565 & 0.0198 & 0.0112 & 0.0117 & 0.0169 & 0.0248 \\
\hline RET_MOM & 29,565 & 0.0083 & 0.1959 & -0.1024 & -0.0002 & 0.1057 \\
\hline $\mathrm{ROA}$ & 28,391 & 0.0815 & 0.1070 & 0.0457 & 0.0840 & 0.1320 \\
\hline LOSS & 29,664 & 0.1742 & 0.3792 & 0.0000 & 0.0000 & 0.0000 \\
\hline$R \& D$ & 29,664 & 0.0706 & 0.2104 & 0.0000 & 0.0000 & 0.0660 \\
\hline FWDLOOK(Present) & 29,664 & 4.4982 & 2.8706 & 2.0000 & 4.0000 & 7.0000 \\
\hline FWDLOOK(Response) & 29,664 & 4.3127 & 2.7561 & 2.0000 & 2.0000 & 7.0000 \\
\hline POSTONE(Present) & 29,664 & 4.4991 & 2.8730 & 2.0000 & 5.0000 & 7.0000 \\
\hline POSTONE(Response) & 29,664 & 4.2655 & 2.7685 & 2.0000 & 2.0000 & 7.0000 \\
\hline NEGTONE(Present) & 29,664 & 4.4992 & 2.8722 & 2.0000 & 4.0000 & 7.0000 \\
\hline NEGTONE(Response) & 29,664 & 4.3651 & 2.7388 & 2.0000 & 2.0000 & 7.0000 \\
\hline GUIDANCE & 29,664 & 0.4002 & 0.4900 & 0.0000 & 0.0000 & 1.0000 \\
\hline
\end{tabular}

Notes: Table 2 presents descriptive statistics for the full sample. Our sample is constructed from the intersection of SeekingAlpha.com, I/B/E/S, and CRSP/Compustat. Panel A reports the descriptive statistics for various variables used in our analysis. Panel B reports the correlation coefficients among these variables. Spearman (Pearson) correlations appear above (below) the diagonal and bold denotes correlations statistically significant at the $1 \%$ level. All variables are defined in Appendix and winsorized at the 1st and 99th percentiles. 


\section{Table 3}

\section{Linguistic Complexity and Future Earnings Growth}

\begin{tabular}{|c|c|c|c|c|c|c|c|}
\hline \multirow{2}{*}{$\begin{array}{l}\text { Dependent Variable } \\
\text { Interaction terms } \\
\text { Variable }\end{array}$} & \multirow[b]{2}{*}{ Exp.Sign } & \multicolumn{6}{|c|}{ 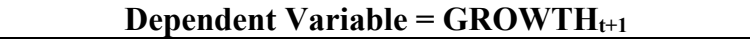 } \\
\hline & & $(1)$ & & $\boldsymbol{I I}_{(2)} \boldsymbol{D} \boldsymbol{A}$ & & $\begin{array}{l}M B E \\
\text { (3) }\end{array}$ & \\
\hline Obfu(Present) & - & $\begin{array}{r}-0.0828 \\
(-2.84)\end{array}$ & $* * *$ & $\begin{array}{r}-0.0754 \\
(-2.07)\end{array}$ & $* *$ & $\begin{array}{r}-0.0779 \\
(-2.59)\end{array}$ & $* * *$ \\
\hline Obfu(Response) & - & $\begin{array}{r}-0.0651 \\
(-2.27)\end{array}$ & $* *$ & $\begin{array}{r}-0.0152 \\
(-0.45)\end{array}$ & & $\begin{array}{r}-0.0516 \\
(-1.65)\end{array}$ & * \\
\hline Info(Both) & + & $\begin{array}{r}0.1141 \\
(2.22)\end{array}$ & $* *$ & $\begin{array}{r}-0.0912 \\
(-1.49)\end{array}$ & & $\begin{array}{r}0.1131 \\
(2.10)\end{array}$ & $* *$ \\
\hline Obfu $($ Present $) * E M$ & - & & & $\begin{array}{r}-0.1094 \\
(-2.14)\end{array}$ & $* *$ & $\begin{array}{r}-0.1576 \\
(-2.37)\end{array}$ & $* *$ \\
\hline Obfu(Response $) * E M$ & - & & & $\begin{array}{r}-0.1429 \\
(-2.36)\end{array}$ & $* *$ & $\begin{array}{r}-0.1292 \\
(-2.09)\end{array}$ & $* *$ \\
\hline Info(Both) $* E M$ & + & & & $\begin{array}{r}0.5100 \\
(4.60)\end{array}$ & $* * *$ & $\begin{array}{r}0.2229 \\
(1.76)\end{array}$ & $*$ \\
\hline II_DA & & & & $\begin{array}{r}-0.2313 \\
(-2.57)\end{array}$ & $* *$ & & \\
\hline$M B E$ & & & & & & $\begin{array}{r}-0.1884 \\
(-1.55)\end{array}$ & \\
\hline$R E T$ & & $\begin{array}{r}0.3983 \\
(2.52)\end{array}$ & $* *$ & $\begin{array}{r}0.3871 \\
(2.36)\end{array}$ & $* *$ & $\begin{array}{r}0.4272 \\
(2.59)\end{array}$ & $* * *$ \\
\hline SIZE & & $\begin{array}{r}0.0748 \\
(2.11)\end{array}$ & $* *$ & $\begin{array}{r}0.0536 \\
(1.58)\end{array}$ & & $\begin{array}{r}0.0611 \\
(1.75)\end{array}$ & $*$ \\
\hline$B M$ & & $\begin{array}{r}-0.8540 \\
(-4.13)\end{array}$ & $* * *$ & $\begin{array}{r}-0.7292 \\
(-3.52)\end{array}$ & $* * *$ & $\begin{array}{r}-1.0043 \\
(-5.13)\end{array}$ & $* * *$ \\
\hline$A F N$ & & $\begin{array}{r}0.0004 \\
(0.09)\end{array}$ & & $\begin{array}{r}0.0011 \\
(0.28)\end{array}$ & & $\begin{array}{r}0.0004 \\
(0.09)\end{array}$ & \\
\hline INST_OWN & & $\begin{array}{r}0.8859 \\
(3.58)\end{array}$ & $* * *$ & $\begin{array}{r}0.8682 \\
(3.72)\end{array}$ & $* * *$ & $\begin{array}{r}0.8618 \\
(3.68)\end{array}$ & $* * *$ \\
\hline$R O A$ & & $\begin{array}{l}-12.536 \\
(-13.44)\end{array}$ & $* * *$ & $\begin{array}{l}-11.585 \\
(-12.45)\end{array}$ & $* * *$ & $\begin{array}{l}-12.448 \\
(-13.52)\end{array}$ & $* * *$ \\
\hline UESURP & & $\begin{array}{r}4.9067 \\
(2.41)\end{array}$ & $* *$ & $\begin{array}{r}4.3945 \\
(2.15)\end{array}$ & $* *$ & $\begin{array}{r}5.0805 \\
(2.50)\end{array}$ & $* *$ \\
\hline FWDLOOK(Present) & & $\begin{array}{r}-0.0290 \\
(-1.50)\end{array}$ & & $\begin{array}{r}-0.0269 \\
(-1.37)\end{array}$ & & $\begin{array}{r}-0.0211 \\
(-1.05)\end{array}$ & \\
\hline FWDLOOK(Response) & & $\begin{array}{r}-0.0082 \\
(-0.24)\end{array}$ & & $\begin{array}{r}-0.0015 \\
(-0.04)\end{array}$ & & $\begin{array}{r}0.0010 \\
(0.03)\end{array}$ & \\
\hline POSTONE(Present) & & $\begin{array}{r}0.0040 \\
(0.25)\end{array}$ & & $\begin{array}{r}0.0168 \\
(1.02)\end{array}$ & & $\begin{array}{r}0.0089 \\
(0.54)\end{array}$ & \\
\hline POSTONE(Response) & & $\begin{array}{r}0.0262 \\
(0.99)\end{array}$ & & $\begin{array}{r}0.0253 \\
(0.98)\end{array}$ & & $\begin{array}{r}0.0285 \\
(1.07)\end{array}$ & \\
\hline NEGTONE(Present) & & $\begin{array}{r}0.0219 \\
(1.11)\end{array}$ & & $\begin{array}{r}0.0116 \\
(0.56)\end{array}$ & & $\begin{array}{r}0.0104 \\
(0.48)\end{array}$ & \\
\hline NEGTONE(Response) & & $\begin{array}{r}-0.0743 \\
(-2.54)\end{array}$ & $* *$ & $\begin{array}{r}-0.0863 \\
(-2.99)\end{array}$ & $* * *$ & $\begin{array}{r}-0.0884 \\
(-3.04)\end{array}$ & $* * *$ \\
\hline GUIDANCE & & $\begin{array}{r}0.3696 \\
(4.34)\end{array}$ & $* * *$ & $\begin{array}{r}0.4015 \\
(4.61)\end{array}$ & $* * *$ & $\begin{array}{r}0.3827 \\
(4.30)\end{array}$ & $* * *$ \\
\hline Firm FE & & YES & & YES & & YES & \\
\hline $\begin{array}{l}\text { No.Obs. } \\
\text { Adj R2 }\end{array}$ & & $\begin{array}{l}28391 \\
4.90 \% \\
\end{array}$ & & $\begin{array}{l}28391 \\
4.50 \% \\
\end{array}$ & & $\begin{array}{l}28391 \\
4.47 \% \\
\end{array}$ & \\
\hline
\end{tabular}

Notes: Table 3 presents results from estimating the relation between the future earnings growth and the latent components of linguistic complexity. All the variables are as defined in Appendix. $t$-statistics appear in parentheses and are based on standard errors clustered by firm and disclosure date of the conference call. $* * *, * *$, and $*$ denote statistical significance at the $0.01,0.05$, and 0.10 levels (two-tail), respectively. 
Table 4

Linguistic Complexity and Analyst Forecast Revisions

\begin{tabular}{|c|c|c|c|c|c|c|c|}
\hline \multirow[b]{2}{*}{$\begin{array}{l}\text { Interaction terms } \\
\text { Variable }\end{array}$} & \multicolumn{7}{|c|}{ Dependent Variable $=$ AF REV } \\
\hline & Exp.Sign & (1) & & $\begin{array}{r}I I \_\boldsymbol{D A} \\
(2)\end{array}$ & & $\begin{array}{r}M B E \\
\text { (3) }\end{array}$ & \\
\hline Obfu(Present) & - & $\begin{array}{r}-0.0001 \\
(-2.18)\end{array}$ & $* *$ & $\begin{array}{r}-0.0001 \\
(-1.28)\end{array}$ & & $\begin{array}{r}-0.0001 \\
(-1.96)\end{array}$ & $* *$ \\
\hline Obfu(Response) & - & $\begin{array}{r}-0.0001 \\
(-2.18)\end{array}$ & $* *$ & $\begin{array}{l}\mathbf{0 . 0 0 0 0} \\
(-0.35)\end{array}$ & & $\begin{array}{r}-0.0001 \\
(-1.68)\end{array}$ & $*$ \\
\hline Info(Both) & + & $\begin{array}{r}0.0004 \\
(3.38)\end{array}$ & $* * *$ & $\begin{array}{r}0.0002 \\
(1.83)\end{array}$ & * & $\begin{array}{r}0.0003 \\
(2.66)\end{array}$ & $* * *$ \\
\hline Obfu $($ Present $) * E M$ & - & & & $\begin{array}{l}0.0000 \\
(-0.29)\end{array}$ & & $\begin{array}{l}\mathbf{0 . 0 0 0 0} \\
(-0.54)\end{array}$ & \\
\hline Obfu(Response $) * E M$ & - & & & $\begin{array}{r}-0.0003 \\
(-2.30)\end{array}$ & $* *$ & $\begin{array}{r}-0.0002 \\
(-2.42)\end{array}$ & $* *$ \\
\hline Info $($ Both $) * E M$ & + & & & $\begin{array}{r}0.0004 \\
(2.00)\end{array}$ & $* *$ & $\begin{array}{r}0.0005 \\
(2.63)\end{array}$ & $* * *$ \\
\hline$I I \_D A$ & & & & $\begin{array}{r}0.0001 \\
(0.58)\end{array}$ & & & \\
\hline$M B E$ & & & & & & $\begin{array}{r}0.0001 \\
(0.38)\end{array}$ & \\
\hline UESURP & & $\begin{array}{r}0.1726 \\
(18.19)\end{array}$ & $* * *$ & $\begin{array}{l}0.1721 \\
(17.80)\end{array}$ & $* * *$ & $\begin{array}{r}0.1727 \\
(18.19)\end{array}$ & $* * *$ \\
\hline AFSTD & & $\begin{array}{r}-0.0313 \\
(-1.93)\end{array}$ & * & $\begin{array}{r}-0.0321 \\
(-2.00)\end{array}$ & $* *$ & $\begin{array}{r}-0.0312 \\
(-1.92)\end{array}$ & $*$ \\
\hline$C A R$ & & $\begin{array}{r}0.0318 \\
(17.77)\end{array}$ & $* * *$ & $\begin{array}{r}0.0318 \\
(17.64)\end{array}$ & $* * *$ & $\begin{array}{r}0.0318 \\
(17.73)\end{array}$ & $* * *$ \\
\hline$\triangle L E P S$ & & $\begin{array}{r}0.1164 \\
(8.54)\end{array}$ & $* * *$ & $\begin{array}{r}0.1169 \\
(8.49)\end{array}$ & $* * *$ & $\begin{array}{r}0.1164 \\
(8.54)\end{array}$ & $* * *$ \\
\hline$R E T$ & & $\begin{array}{r}0.0024 \\
(7.35)\end{array}$ & $* * *$ & $\begin{array}{r}0.0024 \\
(7.43)\end{array}$ & $* * *$ & $\begin{array}{r}0.0024 \\
(7.36)\end{array}$ & $* * *$ \\
\hline SIZE & & $\begin{array}{r}0.0002 \\
(1.85)\end{array}$ & * & $\begin{array}{r}0.0002 \\
(1.85)\end{array}$ & $*$ & $\begin{array}{r}0.0002 \\
(1.87)\end{array}$ & $*$ \\
\hline$B M$ & & $\begin{array}{r}0.0008 \\
(1.68)\end{array}$ & $*$ & $\begin{array}{r}0.0009 \\
(1.91)\end{array}$ & $*$ & $\begin{array}{r}0.0008 \\
(1.72)\end{array}$ & $*$ \\
\hline$A F N$ & & $\begin{array}{l}0.0000 \\
(-1.02)\end{array}$ & & $\begin{array}{l}0.0000 \\
(-0.89)\end{array}$ & & $\begin{array}{l}0.0000 \\
(-1.02)\end{array}$ & \\
\hline INST_OWN & & $\begin{array}{r}-0.0009 \\
(-1.67)\end{array}$ & $*$ & $\begin{array}{r}-0.0009 \\
(-1.85)\end{array}$ & $*$ & $\begin{array}{r}-0.0009 \\
(-1.68)\end{array}$ & $*$ \\
\hline FWDLOOK(Present) & & $\begin{array}{l}0.0000 \\
(-0.51)\end{array}$ & & $\begin{array}{l}0.0000 \\
(-1.06)\end{array}$ & & $\begin{array}{l}0.0000 \\
(-0.51)\end{array}$ & \\
\hline FWDLOOK(Response) & & $\begin{array}{r}0.0000 \\
(0.29)\end{array}$ & & $\begin{array}{r}0.0000 \\
(0.11)\end{array}$ & & $\begin{array}{r}0.0000 \\
(0.28)\end{array}$ & \\
\hline POSTONE(Present) & & $\begin{array}{r}0.0000 \\
(0.67)\end{array}$ & & $\begin{array}{r}0.0000 \\
(0.53)\end{array}$ & & $\begin{array}{r}0.0000 \\
(0.68)\end{array}$ & \\
\hline POSTONE(Response) & & $\begin{array}{l}0.0000 \\
(-0.11)\end{array}$ & & $\begin{array}{r}0.0000 \\
(0.04)\end{array}$ & & $\begin{array}{l}0.0000 \\
(-0.09)\end{array}$ & \\
\hline NEGTONE(Present) & & $\begin{array}{r}0.0000 \\
(0.22)\end{array}$ & & $\begin{array}{r}0.0000 \\
(0.30)\end{array}$ & & $\begin{array}{r}0.0000 \\
(0.22)\end{array}$ & \\
\hline NEGTONE(Response) & & $\begin{array}{r}0.0001 \\
(0.91)\end{array}$ & & $\begin{array}{r}0.0001 \\
(0.98)\end{array}$ & & $\begin{array}{r}0.0001 \\
(0.88)\end{array}$ & \\
\hline GUIDANCE & & $\begin{array}{r}0.0000 \\
(0.23)\end{array}$ & & $\begin{array}{l}0.0000 \\
(-0.15)\end{array}$ & & $\begin{array}{r}0.0000 \\
(0.25)\end{array}$ & \\
\hline Firm FE & & YES & & YES & & YES & \\
\hline $\begin{array}{l}\text { No. Obs. } \\
\text { Adj R2 }\end{array}$ & & $\begin{array}{r}29,664 \\
22.17 \%\end{array}$ & & $\begin{array}{r}29,664 \\
22.07 \%\end{array}$ & & $\begin{array}{r}29,664 \\
22.18 \%\end{array}$ & \\
\hline
\end{tabular}

Notes: Table 4 presents results from estimating the relation between analyst forecast revisions and the latent components of linguistic complexity. All the variables are as defined in Appendix. $t$-statistics appear in parentheses and are based on standard errors clustered by firm and disclosure date of the conference call. ***,**, and * denote statistical significance at the $0.01,0.05$, and 0.10 levels (two-tail), respectively. 
Table 5

Linguistic Complexity and Abnormal Returns at the Conference Call

\begin{tabular}{|c|c|c|c|c|c|c|c|}
\hline \multirow{3}{*}{$\begin{array}{l}\text { Interaction terms } \\
\text { Variable }\end{array}$} & & \multicolumn{6}{|c|}{ Dependent Variable $=$ CAR } \\
\hline & & & & II_DA & & $M B E$ & \\
\hline & Exp.Sign & (1) & & (2) & & (3) & \\
\hline Obfu(Present) & - & $\begin{array}{r}-0.0011 \\
(-3.02)\end{array}$ & $* * *$ & $\begin{array}{r}-0.0015 \\
(-3.20)\end{array}$ & $* * *$ & $\begin{array}{r}-0.0011 \\
(-2.98)\end{array}$ & $* * *$ \\
\hline Obfu(Response) & - & $\begin{array}{r}-0.0011 \\
(-2.66)\end{array}$ & $* * *$ & $\begin{array}{r}-0.0007 \\
(-1.56)\end{array}$ & & $\begin{array}{r}-0.0009 \\
(-2.18)\end{array}$ & $* *$ \\
\hline Info(Both) & + & $\begin{array}{r}-0.0005 \\
(-0.66)\end{array}$ & & $\begin{array}{r}-\mathbf{0 . 0 0 0 5} \\
(-0.68)\end{array}$ & & $\begin{array}{r}-0.0007 \\
(-1.09)\end{array}$ & \\
\hline Obfu $($ Present $) * E M$ & - & & & $\begin{array}{r}0.0008 \\
(1.20)\end{array}$ & & $\begin{array}{l}0.0000 \\
(-0.04)\end{array}$ & \\
\hline Obfu(Response $) * E M$ & - & & & $\begin{array}{r}-0.0011 \\
(-1.52)\end{array}$ & & $\begin{array}{r}-0.0018 \\
(-1.70)\end{array}$ & * \\
\hline Info $($ Both $) * E M$ & + & & & $\begin{array}{r}\mathbf{0 . 0 0 0 0} \\
(\mathbf{0 . 0 0 )}\end{array}$ & & $\begin{array}{r}0.0029 \\
(1.20)\end{array}$ & \\
\hline II_DA & & & & $\begin{array}{r}-0.0028 \\
(-2.17)\end{array}$ & ** & & \\
\hline$M B E$ & & & & & & $\begin{array}{l}-0.002 \\
(-1.17)\end{array}$ & \\
\hline$D S U E$ & & $\begin{array}{r}0.0444 \\
(13.11)\end{array}$ & $* * *$ & $\begin{array}{r}0.044 \\
(13.19)\end{array}$ & $* * *$ & $\begin{array}{r}0.044 \\
(13.19)\end{array}$ & $* * *$ \\
\hline$\triangle L E P S$ & & $\begin{array}{l}0.287 \\
(7.86)\end{array}$ & $* * *$ & $\begin{array}{r}0.289 \\
(7.91)\end{array}$ & $* * *$ & $\begin{array}{l}0.286 \\
(7.85)\end{array}$ & $* * *$ \\
\hline$S I Z E$ & & $\begin{array}{r}0.0001 \\
(0.23)\end{array}$ & & $\begin{array}{r}0.0001 \\
(0.24)\end{array}$ & & $\begin{array}{r}0.0001 \\
(0.19)\end{array}$ & \\
\hline$B M$ & & $\begin{array}{l}0.002 \\
(0.92)\end{array}$ & & $\begin{array}{r}0.0022 \\
(1.09)\end{array}$ & & $\begin{array}{r}0.0018 \\
(0.88)\end{array}$ & \\
\hline$R E T \_V O L$ & & $\begin{array}{l}0.271 \\
(3.38)\end{array}$ & $* * *$ & $\begin{array}{l}0.264 \\
(3.31)\end{array}$ & $* * *$ & $\begin{array}{l}0.267 \\
(3.36)\end{array}$ & $* * *$ \\
\hline RET_MOM & & $\begin{array}{r}-0.0214 \\
(-6.05)\end{array}$ & $* * *$ & $\begin{array}{r}-0.0213 \\
(-6.07)\end{array}$ & $* * *$ & $\begin{array}{r}-0.0213 \\
(-6.03)\end{array}$ & $* * *$ \\
\hline$A F N$ & & $\begin{array}{r}-0.0001 \\
(-1.71)\end{array}$ & $*$ & $\begin{array}{r}-0.0001 \\
(-1.70)\end{array}$ & $*$ & $\begin{array}{r}-0.0001 \\
(-1.73)\end{array}$ & $*$ \\
\hline INST_OWN & & $\begin{array}{l}0.007 \\
(2.37)\end{array}$ & $* *$ & $\begin{array}{r}0.0074 \\
(2.41)\end{array}$ & $* *$ & $\begin{array}{r}0.0071 \\
(2.35)\end{array}$ & $* *$ \\
\hline$A F S T D$ & & $\begin{array}{r}-0.0608 \\
(-1.43)\end{array}$ & & $\begin{array}{r}-0.0595 \\
(-1.39)\end{array}$ & & $\begin{array}{r}-0.0634 \\
(-1.48)\end{array}$ & \\
\hline SPECIAL & & $\begin{array}{r}-0.0027 \\
(-2.42)\end{array}$ & $* *$ & $\begin{array}{l}-0.003 \\
(-2.46)\end{array}$ & $* *$ & $\begin{array}{l}-0.003 \\
(-2.43)\end{array}$ & $* *$ \\
\hline 4thQTR & & $\begin{array}{r}0.0018 \\
(1.72)\end{array}$ & $*$ & $\begin{array}{r}0.0020 \\
(1.83)\end{array}$ & * & $\begin{array}{r}0.0018 \\
(1.70)\end{array}$ & $*$ \\
\hline RESPONSIVE & & $\begin{array}{r}0.0019 \\
(1.51)\end{array}$ & & $\begin{array}{r}0.0020 \\
(1.53)\end{array}$ & & $\begin{array}{r}0.0019 \\
(1.47)\end{array}$ & \\
\hline BNEWS & & $\begin{array}{r}-0.0065 \\
(-4.11)\end{array}$ & $* * *$ & $\begin{array}{r}-0.0065 \\
(-4.11)\end{array}$ & $* * *$ & $\begin{array}{r}-0.0066 \\
(-4.13)\end{array}$ & $* * *$ \\
\hline FWDLOOK(Present) & & $\begin{array}{r}-0.0004 \\
(-1.41)\end{array}$ & & $\begin{array}{r}-0.0004 \\
(-1.41)\end{array}$ & & $\begin{array}{r}-0.0004 \\
(-1.41)\end{array}$ & \\
\hline FWDLOOK(Response) & & $\begin{array}{r}-0.0006 \\
(-1.43)\end{array}$ & & $\begin{array}{r}-0.0006 \\
(-1.44)\end{array}$ & & $\begin{array}{r}-0.0006 \\
(-1.44)\end{array}$ & \\
\hline POSTONE(Present) & & $\begin{array}{r}-0.0003 \\
(-1.04)\end{array}$ & & $\begin{array}{r}-0.0003 \\
(-1.06)\end{array}$ & & $\begin{array}{r}-0.0003 \\
(-1.05)\end{array}$ & \\
\hline POSTONE(Response) & & $\begin{array}{r}0.0005 \\
(1.82)\end{array}$ & $*$ & $\begin{array}{r}0.0005 \\
(1.75)\end{array}$ & $*$ & $\begin{array}{r}0.0006 \\
(1.82)\end{array}$ & $*$ \\
\hline NEGTONE(Present) & & $\begin{array}{r}0.0000 \\
(0.16)\end{array}$ & & $\begin{array}{r}0.0000 \\
(0.11)\end{array}$ & & $\begin{array}{r}0.0000 \\
(0.14)\end{array}$ & \\
\hline NEGTONE(Response) & & $\begin{array}{r}0.0003 \\
(0.77)\end{array}$ & & $\begin{array}{r}0.0003 \\
(0.76)\end{array}$ & & $\begin{array}{r}0.0002 \\
(0.74)\end{array}$ & \\
\hline GUIDANCE & & $\begin{array}{r}-0.0015 \\
(-1.08)\end{array}$ & & $\begin{array}{r}-0.0014 \\
(-1.06)\end{array}$ & & $\begin{array}{r}-0.0014 \\
(-1.06)\end{array}$ & \\
\hline Firm FE & & YES & & YES & & YES & \\
\hline $\begin{array}{l}\text { No. Obs. } \\
\text { Adj R2 }\end{array}$ & & $\begin{array}{r}29,103 \\
6.438 \%\end{array}$ & & $\begin{array}{r}29,103 \\
6.487 \%\end{array}$ & & $\begin{array}{r}29,103 \\
6.467 \%\end{array}$ & \\
\hline
\end{tabular}

Notes: Table 5 presents results from estimating the relation between the stock returns to the conference calls and the latent components of linguistic complexity. All the variables are as defined in Appendix. $t$-statistics appear in parentheses and are based on standard errors clustered by firm and disclosure date of the conference call. ***, **, and * denote statistical significance at the $0.01,0.05$, and 0.10 levels (two-tail), respectively. 
Table 6

\section{Linguistic Complexity and Post Conference Call Returns and Analyst Forecasts}

Panel A: Linguistic Complexity and Post Conference Call Returns

\begin{tabular}{|c|c|c|c|c|c|c|c|}
\hline \multirow[b]{2}{*}{$\begin{array}{l}\text { Interaction terms } \\
\text { Variable }\end{array}$} & \multirow[b]{2}{*}{ Exp.Sign } & \multicolumn{6}{|c|}{ Dependent Variable $=$ POST_CAR } \\
\hline & & $(1)$ & & $\begin{array}{c}I_{(2)} \boldsymbol{D A} \\
(2)\end{array}$ & & $\begin{array}{l}M B E \\
\text { (3) }\end{array}$ & \\
\hline Obfu(Present) & $?$ & $\begin{array}{r}-0.0012 \\
(-1.39)\end{array}$ & & $\begin{array}{r}-0.0002 \\
(-0.2)\end{array}$ & & $\begin{array}{r}-0.0011 \\
(-1.29)\end{array}$ & \\
\hline Obfu(Response) & $?$ & $\begin{array}{l}0.0000 \\
(-0.03)\end{array}$ & & $\begin{array}{r}-0.0006 \\
(-0.59)\end{array}$ & & $\begin{array}{r}-0.0003 \\
(-0.39)\end{array}$ & \\
\hline Info(Both) & + & $\begin{array}{r}0.0053 \\
(3.87)\end{array}$ & $* * *$ & $\begin{array}{r}\mathbf{0 . 0 0 3 1} \\
(\mathbf{1 . 8 5})\end{array}$ & $*$ & $\begin{array}{r}0.0042 \\
(3.01)\end{array}$ & $* * *$ \\
\hline Obfu $($ Present $) * E M$ & $?$ & & & $\begin{array}{r}-0.0025 \\
(-1.72)\end{array}$ & $*$ & $\begin{array}{r}-0.0011 \\
(-0.44)\end{array}$ & \\
\hline Obfu(Response $) * E M$ & $?$ & & & $\begin{array}{r}0.0015 \\
(1.03)\end{array}$ & & $\begin{array}{r}0.0027 \\
(1.34)\end{array}$ & \\
\hline $\operatorname{Info}($ Both $) * E M$ & + & & & $\begin{array}{r}0.0063 \\
(2.26)\end{array}$ & $* *$ & $\begin{array}{r}0.0104 \\
(2.58)\end{array}$ & $* * *$ \\
\hline II_DA & & & & $\begin{array}{r}-0.0009 \\
(-0.40)\end{array}$ & & & \\
\hline$M B E$ & & & & & & $\begin{array}{r}0.0080 \\
(2.08)\end{array}$ & $* *$ \\
\hline DSUE & & $\begin{array}{c}0.0984 \\
(14.00)\end{array}$ & $* * *$ & $\begin{array}{c}0.0981 \\
(13.98)\end{array}$ & $* * *$ & $\begin{array}{r}0.0985 \\
(14.04)\end{array}$ & $* * *$ \\
\hline$\triangle L E P S$ & & $\begin{array}{r}0.0204 \\
(0.19)\end{array}$ & & $\begin{array}{r}0.0210 \\
(0.19)\end{array}$ & & $\begin{array}{r}0.0222 \\
(0.21)\end{array}$ & \\
\hline SIZE & & $\begin{array}{r}0.0037 \\
(3.32)\end{array}$ & $* * *$ & $\begin{array}{r}0.0037 \\
(3.38)\end{array}$ & $* * *$ & $\begin{array}{r}0.0038 \\
(3.41)\end{array}$ & $* * *$ \\
\hline$B M$ & & $\begin{array}{r}0.0107 \\
(2.49)\end{array}$ & $* *$ & $\begin{array}{r}0.0109 \\
(2.52)\end{array}$ & $* *$ & $\begin{array}{r}0.0112 \\
(2.60)\end{array}$ & $* * *$ \\
\hline$R E T \_V O L$ & & $\begin{array}{r}1.3852 \\
(8.55)\end{array}$ & $* * *$ & $\begin{array}{r}1.3894 \\
(8.66)\end{array}$ & $* * *$ & $\begin{array}{r}1.3915 \\
(8.61)\end{array}$ & $* * *$ \\
\hline$R E T \_M O M$ & & $\begin{array}{r}-0.0177 \\
(-2.03)\end{array}$ & $* *$ & $\begin{array}{r}-0.0177 \\
(-2.04)\end{array}$ & $* *$ & $\begin{array}{r}-0.0178 \\
(-2.06)\end{array}$ & $* *$ \\
\hline$A F N$ & & $\begin{array}{r}-0.0005 \\
(-4.20)\end{array}$ & $* * *$ & $\begin{array}{r}-0.0005 \\
(-4.27)\end{array}$ & $* * *$ & $\begin{array}{r}-0.0005 \\
(-4.14)\end{array}$ & $* * *$ \\
\hline INST_OWN & & $\begin{array}{r}0.0038 \\
(0.57)\end{array}$ & & $\begin{array}{r}0.0037 \\
(0.56)\end{array}$ & & $\begin{array}{r}0.0042 \\
(0.65)\end{array}$ & \\
\hline AFSTD & & $\begin{array}{r}-0.4213 \\
(-3.81)\end{array}$ & $* * *$ & $\begin{array}{r}-0.4218 \\
(-3.82)\end{array}$ & $* * *$ & $\begin{array}{r}-0.4105 \\
(-3.73)\end{array}$ & $* * *$ \\
\hline SPECIAL & & $\begin{array}{r}-0.0054 \\
(-2.45)\end{array}$ & $* *$ & $\begin{array}{r}-0.0055 \\
(-2.47)\end{array}$ & $* *$ & $\begin{array}{r}-0.0054 \\
(-2.44)\end{array}$ & $* *$ \\
\hline $4 \operatorname{th} Q T R$ & & $\begin{array}{r}0.0046 \\
(1.99)\end{array}$ & $* *$ & $\begin{array}{r}0.0047 \\
(2.05)\end{array}$ & $* *$ & $\begin{array}{r}0.0047 \\
(2.06)\end{array}$ & $* *$ \\
\hline RESPONSIVE & & $\begin{array}{r}0.0029 \\
(1.08)\end{array}$ & & $\begin{array}{r}0.0028 \\
(1.04)\end{array}$ & & $\begin{array}{r}0.0030 \\
(1.13)\end{array}$ & \\
\hline$B N E W S$ & & $\begin{array}{r}0.0022 \\
(0.59)\end{array}$ & & $\begin{array}{r}0.0022 \\
(0.57)\end{array}$ & & $\begin{array}{r}0.0022 \\
(0.59)\end{array}$ & \\
\hline FWDLOOK(Present) & & $\begin{array}{r}-0.0001 \\
(-0.25)\end{array}$ & & $\begin{array}{r}-0.0001 \\
(-0.22)\end{array}$ & & $\begin{array}{r}-0.0001 \\
(-0.23)\end{array}$ & \\
\hline FWDLOOK(Response) & & $\begin{array}{r}-0.0008 \\
(-1.00)\end{array}$ & & $\begin{array}{r}-0.0007 \\
(-0.98)\end{array}$ & & $\begin{array}{r}-0.0007 \\
(-0.98)\end{array}$ & \\
\hline POSTONE(Present) & & $\begin{array}{r}0.0005 \\
(0.97)\end{array}$ & & $\begin{array}{r}0.0005 \\
(0.96)\end{array}$ & & $\begin{array}{r}0.0005 \\
(1.01)\end{array}$ & \\
\hline POSTONE(Response) & & $\begin{array}{r}-0.0006 \\
(-1.00)\end{array}$ & & $\begin{array}{r}-0.0006 \\
(-1.03)\end{array}$ & & $\begin{array}{r}-0.0005 \\
(-0.95)\end{array}$ & \\
\hline NEGTONE(Present) & & $\begin{array}{r}0.0006 \\
(1.19)\end{array}$ & & $\begin{array}{l}0.0006 \\
(1.197)\end{array}$ & & $\begin{array}{r}0.0006 \\
(1.20)\end{array}$ & \\
\hline NEGTONE(Response) & & $\begin{array}{r}-0.0004 \\
(-0.56)\end{array}$ & & $\begin{array}{r}-0.0005 \\
(-0.62)\end{array}$ & & $\begin{array}{r}-0.0004 \\
(-0.61)\end{array}$ & \\
\hline GUIDANCE & & $\begin{array}{r}-0.0002 \\
(-0.10)\end{array}$ & & $\begin{array}{r}-0.0002 \\
(-0.11)\end{array}$ & & $\begin{array}{r}-0.0003 \\
(-0.14)\end{array}$ & \\
\hline Firm FE & & YES & & YES & & YES & \\
\hline $\begin{array}{l}\text { No. Obs. } \\
\text { Adj R2 }\end{array}$ & & $\begin{array}{r}29,225 \\
5.277 \%\end{array}$ & & $\begin{array}{r}29,225 \\
5.312 \%\end{array}$ & & $\begin{array}{r}29,225 \\
5.335 \%\end{array}$ & \\
\hline
\end{tabular}


Table 6

\section{Linguistic Complexity and Post Conference Call Returns and Analyst Forecasts}

Panel B: Market Reactions to Initial Analyst Forecasts and Linguistic Complexity

\begin{tabular}{|c|c|c|c|c|c|c|}
\hline \multirow{3}{*}{$\begin{array}{l}\text { Interaction terms } \\
\text { Variable }\end{array}$} & \multicolumn{6}{|c|}{ DV = CAR_AnalystReport } \\
\hline & \multirow{2}{*}{\multicolumn{2}{|c|}{$(1)$}} & \multicolumn{2}{|c|}{ II_DA } & \\
\hline & & & $-(2)$ & & (3) & \\
\hline \multirow[t]{2}{*}{ Obfu(Present) } & -0.0001 & & 0.0001 & & -0.0001 & \\
\hline & $(-0.57)$ & & $(0.36)$ & & $(-0.41)$ & \\
\hline \multirow[t]{2}{*}{ Obfu(Response) } & -0.0002 & & -0.0003 & & -0.0003 & \\
\hline & $(-1.19)$ & & $(-1.17)$ & & $(-1.41)$ & \\
\hline \multirow[t]{2}{*}{ Info(Both) } & 0.0013 & $* * *$ & 0.0008 & $*$ & 0.0012 & $* * *$ \\
\hline & (3.57) & & $(1.81)$ & & $(2.97)$ & \\
\hline \multirow[t]{2}{*}{ Obfu $($ Present $) * E M$} & & & -0.0005 & & -0.0003 & \\
\hline & & & $(-1.41)$ & & $(-0.63)$ & \\
\hline \multirow[t]{2}{*}{ Obfu(Response) $* E M$} & & & 0.0002 & & 0.0007 & \\
\hline & & & $(0.37)$ & & (1.29) & \\
\hline \multirow[t]{2}{*}{$\operatorname{Info}($ Both $) * E M$} & & & 0.0013 & $*$ & 0.0020 & $*$ \\
\hline & & & (1.83) & & (1.89) & \\
\hline \multirow[t]{2}{*}{$I I \_D A$} & & & -0.0002 & & & \\
\hline & & & $(-0.27)$ & & & \\
\hline \multirow[t]{2}{*}{$M B E$} & & & & & -0.0001 & \\
\hline & & & & & $(-0.17)$ & \\
\hline \multirow[t]{2}{*}{$D S U E$} & 0.0037 & $* *$ & 0.0037 & $* *$ & 0.0037 & $* *$ \\
\hline & $(2.02)$ & & $(1.99)$ & & $(2.00)$ & \\
\hline \multirow[t]{2}{*}{$\triangle L E P S$} & 0.0478 & $*$ & 0.0478 & $*$ & 0.0479 & * \\
\hline & $(1.92)$ & & $(1.92)$ & & $(1.92)$ & \\
\hline SIZE & -0.0001 & & 0.0000 & & -0.0001 & \\
\hline & $(-0.22)$ & & $(-0.16)$ & & $(-0.24)$ & \\
\hline$B M$ & -0.0003 & & -0.0002 & & -0.0003 & \\
\hline & $(-0.22)$ & & $(-0.20)$ & & $(-0.22)$ & \\
\hline$R E T \_V O L$ & 0.0860 & $*$ & 0.0871 & * & 0.0856 & * \\
\hline & $(1.75)$ & & $(1.76)$ & & $(1.74)$ & \\
\hline RET_MOM & -0.0031 & & -0.0031 & & -0.0031 & \\
\hline & $(-1.46)$ & & $(-1.46)$ & & $(-1.47)$ & \\
\hline$A F N$ & 0.0000 & $*$ & 0.0000 & $* *$ & 0.0000 & $* *$ \\
\hline & $(-1.94)$ & & $(-1.97)$ & & $(-1.96)$ & \\
\hline INST_OWN & -0.0012 & & -0.0012 & & -0.0012 & \\
\hline & $(-0.74)$ & & $(-0.75)$ & & $(-0.73)$ & \\
\hline AFSTD & -0.0543 & & -0.0544 & & -0.0543 & \\
\hline & $(-1.58)$ & & $(-1.58)$ & & $(-1.57)$ & \\
\hline SPECIAL & -0.0003 & & -0.0004 & & -0.0003 & \\
\hline & $(-0.61)$ & & $(-0.64)$ & & $(-0.61)$ & \\
\hline 4thQTR & 0.0004 & & 0.0005 & & 0.0004 & \\
\hline & $(0.69)$ & & $(0.75)$ & & $(0.71)$ & \\
\hline RESPONSIVE & -0.0009 & & -0.0010 & & -0.0009 & \\
\hline & $(-1.16)$ & & $(-1.19)$ & & $(-1.17)$ & \\
\hline$B N E W S$ & -0.0008 & & -0.0008 & & -0.0008 & \\
\hline & $(-0.86)$ & & $(-0.88)$ & & $(-0.88)$ & \\
\hline FWDLOOK(Present) & 0.0000 & & 0.0000 & & 0.0000 & \\
\hline & $(-0.14)$ & & $(-0.11)$ & & $(-0.12)$ & \\
\hline FWDLOOK(Response) & -0.0003 & & -0.0003 & & -0.0003 & \\
\hline & $(-1.38)$ & & $(-1.36)$ & & $(-1.38)$ & \\
\hline POSTONE(Present) & 0.0000 & & 0.0000 & & 0.0000 & \\
\hline & $(0.07)$ & & $(0.05)$ & & $(0.08)$ & \\
\hline POSTONE(Response) & 0.0001 & & 0.0001 & & 0.0001 & \\
\hline & $(0.65)$ & & $(0.64)$ & & $(0.69)$ & \\
\hline NEGTONE(Present) & 0.0000 & & 0.0000 & & 0.0000 & \\
\hline & $(0.33)$ & & $(0.31)$ & & $(0.33)$ & \\
\hline NEGTONE(Response) & 0.0001 & & 0.0001 & & 0.0001 & \\
\hline & $(0.71)$ & & $(0.65)$ & & $(0.68)$ & \\
\hline GUIDANCE & 0.0002 & & 0.0002 & & 0.0002 & \\
\hline & $(0.30)$ & & $(0.30)$ & & $(0.29)$ & \\
\hline Firm FE & YES & & YES & & YES & \\
\hline No.Obs. & 21,344 & & 21,344 & & 21,344 & \\
\hline Adj R2 & $1.410 \%$ & & $1.435 \%$ & & $1.428 \%$ & \\
\hline
\end{tabular}

Notes: Table 6 presents results from estimating the relation between the latent components of linguistic complexity and the market reactions to the first analyst reports. All the variables are as defined in Appendix. t-statistics appear in parentheses and are based on standard errors clustered by firm and disclosure date of the conference call. ${ }^{* *}, * *$, and $*$ denote statistical significance at the $0.01,0.05$, and 0.10 levels (two-tail), respectively. 
Table 7

Linguistic Complexity and Management Forecast Precision

\begin{tabular}{|c|c|c|c|c|c|c|c|}
\hline \multirow{3}{*}{$\begin{array}{l}\text { Interaction terms } \\
\text { Variable }\end{array}$} & \multicolumn{7}{|c|}{ Dependent Variable = MGMT_PRECISION } \\
\hline & & & & II_DA & & $M B E$ & \\
\hline & Exp.Sign & (1) & & (2) & & (3) & \\
\hline Obfu(Present) & - & $\begin{array}{r}0.0000 \\
(0.66)\end{array}$ & & $\begin{array}{r}0.0000 \\
(0.62)\end{array}$ & & $\begin{array}{r}0.0000 \\
(0.37)\end{array}$ & \\
\hline Obfu(Response) & - & $\begin{array}{r}-0.0001 \\
(-2.53)\end{array}$ & $* *$ & $\begin{array}{r}-0.0001 \\
(-2.09)\end{array}$ & $* *$ & $\begin{array}{r}-0.0001 \\
(-1.83)\end{array}$ & * \\
\hline Info(Both) & + & $\begin{array}{r}0.0001 \\
(2.31)\end{array}$ & $* *$ & $\begin{array}{r}0.0002 \\
(2.66)\end{array}$ & $* * *$ & $\begin{array}{r}0.0001 \\
(2.23)\end{array}$ & $* *$ \\
\hline Obfu $($ Present $) * E M$ & - & & & $\begin{array}{l}0.0000 \\
(-0.26)\end{array}$ & & $\begin{array}{r}0.0001 \\
(1.11)\end{array}$ & \\
\hline Obfu(Response $) * E M$ & - & & & $\begin{array}{l}0.0000 \\
(-0.27)\end{array}$ & & $\begin{array}{r}-0.0002 \\
(-2.22)\end{array}$ & $* *$ \\
\hline Info $($ Both $) * E M$ & + & & & $\begin{array}{r}-0.0002 \\
(-1.39)\end{array}$ & & $\begin{array}{r}-0.0001 \\
(-0.45)\end{array}$ & \\
\hline II_DA & & & & $\begin{array}{r}-0.0001 \\
(-0.66)\end{array}$ & & & \\
\hline$M B E$ & & & & & & $\begin{array}{r}0.000 \\
(3.47)\end{array}$ & $* * *$ \\
\hline DSUE & & $\begin{array}{r}-0.0007 \\
(-1.91)\end{array}$ & $*$ & $\begin{array}{l}-0.001 \\
(-1.90)\end{array}$ & $*$ & $\begin{array}{l}-0.001 \\
(-1.82)\end{array}$ & $*$ \\
\hline$\triangle L E P S$ & & $\begin{array}{l}-0.007 \\
(-0.77)\end{array}$ & & $\begin{array}{l}-0.007 \\
(-0.77)\end{array}$ & & $\begin{array}{l}-0.007 \\
(-0.72)\end{array}$ & \\
\hline SIZE & & $\begin{array}{r}0.0001 \\
(2.23)\end{array}$ & $* *$ & $\begin{array}{r}0.0001 \\
(2.24)\end{array}$ & $* *$ & $\begin{array}{r}0.0001 \\
(2.36)\end{array}$ & $* *$ \\
\hline$B M$ & & $\begin{array}{r}-0.004 \\
(-12.87)\end{array}$ & $* * *$ & $\begin{array}{l}-0.0039 \\
(-12.73)\end{array}$ & $* * *$ & $\begin{array}{l}-0.0039 \\
(-12.84)\end{array}$ & $* * *$ \\
\hline$R E T \_V O L$ & & $\begin{array}{l}-0.078 \\
(-7.77)\end{array}$ & $* * *$ & $\begin{array}{l}-0.078 \\
(-7.82)\end{array}$ & $* * *$ & $\begin{array}{l}-0.078 \\
(-7.80)\end{array}$ & $* * *$ \\
\hline$R E T \_M O M$ & & $\begin{array}{r}0.0036 \\
(7.73)\end{array}$ & $* * *$ & $\begin{array}{r}0.0036 \\
(7.78)\end{array}$ & $* * *$ & $\begin{array}{r}0.0036 \\
(7.90)\end{array}$ & $* * *$ \\
\hline$A F N$ & & $\begin{array}{r}0.0000 \\
(1.98)\end{array}$ & $* *$ & $\begin{array}{r}0.0000 \\
(1.96)\end{array}$ & $*$ & $\begin{array}{r}0.0000 \\
(1.97)\end{array}$ & $* *$ \\
\hline INST_OWN & & $\begin{array}{l}0.001 \\
(2.45)\end{array}$ & $* *$ & $\begin{array}{r}0.0010 \\
(2.52)\end{array}$ & $* *$ & $\begin{array}{r}0.0010 \\
(2.59)\end{array}$ & $* * *$ \\
\hline$A F S T D$ & & $\begin{array}{r}-0.1221 \\
(-5.80)\end{array}$ & $* * *$ & $\begin{array}{r}-0.1219 \\
(-5.79)\end{array}$ & $* * *$ & $\begin{array}{r}-0.1211 \\
(-5.76)\end{array}$ & $* * *$ \\
\hline SPECIAL & & $\begin{array}{l}0.0000 \\
(-0.14)\end{array}$ & & $\begin{array}{r}0.000 \\
(-0.15)\end{array}$ & & $\begin{array}{r}0.000 \\
(-0.06)\end{array}$ & \\
\hline $4 \operatorname{th} Q T R$ & & $\begin{array}{r}-0.0009 \\
(-6.25)\end{array}$ & $* * *$ & $\begin{array}{r}-0.0009 \\
(-6.26)\end{array}$ & $* * *$ & $\begin{array}{r}-0.0009 \\
(-6.24)\end{array}$ & $* * *$ \\
\hline RESPONSIVE & & $\begin{array}{r}-0.0001 \\
(-0.47)\end{array}$ & & $\begin{array}{r}-0.0001 \\
(-0.46)\end{array}$ & & $\begin{array}{r}-0.0001 \\
(-0.42)\end{array}$ & \\
\hline BNEWS & & $\begin{array}{r}-0.0007 \\
(-4.66)\end{array}$ & $* * *$ & $\begin{array}{r}-0.0007 \\
(-4.68)\end{array}$ & $* * *$ & $\begin{array}{r}-0.0006 \\
(-4.62)\end{array}$ & $* * *$ \\
\hline FWDLOOK(Present) & & $\begin{array}{r}0.0000 \\
(0.78)\end{array}$ & & $\begin{array}{r}0.0000 \\
(0.82)\end{array}$ & & $\begin{array}{r}0.0000 \\
(0.80)\end{array}$ & \\
\hline FWDLOOK(Response) & & $\begin{array}{r}0.0000 \\
(0.21)\end{array}$ & & $\begin{array}{r}0.0000 \\
(0.23)\end{array}$ & & $\begin{array}{r}0.0000 \\
(0.17)\end{array}$ & \\
\hline POSTONE(Present) & & $\begin{array}{l}0.0000 \\
(-1.59)\end{array}$ & & $\begin{array}{l}0.0000 \\
(-1.58)\end{array}$ & & $\begin{array}{l}0.0000 \\
(-1.59)\end{array}$ & \\
\hline POSTONE(Response) & & $\begin{array}{r}0.0000 \\
(1.78)\end{array}$ & $*$ & $\begin{array}{r}0.0000 \\
(1.77)\end{array}$ & $*$ & $\begin{array}{r}0.0000 \\
(1.84)\end{array}$ & $*$ \\
\hline NEGTONE(Present) & & $\begin{array}{r}0.0000 \\
(0.14)\end{array}$ & & $\begin{array}{r}0.0000 \\
(0.12)\end{array}$ & & $\begin{array}{r}0.0000 \\
(0.07)\end{array}$ & \\
\hline NEGTONE(Response) & & $\begin{array}{r}-0.0001 \\
(-1.52)\end{array}$ & & $\begin{array}{r}-0.0001 \\
(-1.53)\end{array}$ & & $\begin{array}{r}-0.0001 \\
(-1.51)\end{array}$ & \\
\hline GUIDANCE & & $\begin{array}{r}0.0000 \\
(0.30)\end{array}$ & & $\begin{array}{r}0.0000 \\
(0.31)\end{array}$ & & $\begin{array}{r}0.0000 \\
(0.31)\end{array}$ & \\
\hline Firm FE & & YES & & YES & & YES & \\
\hline $\begin{array}{l}\text { No.Obs. } \\
\text { Adj R2 }\end{array}$ & & $\begin{array}{r}8,035 \\
27.39 \% \\
\end{array}$ & & $\begin{array}{r}8,035 \\
27.42 \% \\
\end{array}$ & & $\begin{array}{r}8,035 \\
27.53 \% \\
\end{array}$ & \\
\hline
\end{tabular}

Notes: Table 7 presents results from estimating the relation between the latent components of linguistic complexity and the management forecast precision. All the variables are as defined in Appendix. t-statistics appear in parentheses and are based on standard errors clustered by firm and disclosure date of the conference call. $* * *, * *$, and $*$ denote statistical significance at the $0.01,0.05$, and 0.10 levels (two-tail), respectively. 
Table 8

Linguistic Complexity and Analyst Forecast Accuracy and Dispersion

Panel A: Linguistic Complexity and Analyst Forecast Accuracy

\begin{tabular}{|c|c|c|c|c|c|c|c|}
\hline \multirow{3}{*}{$\begin{array}{l}\text { Interaction terms } \\
\text { Variable }\end{array}$} & \multicolumn{6}{|c|}{ Dependent Variable $=\Delta \mathrm{AF} \quad \mathrm{ACCR}$} & \\
\hline & & & & II $\overline{D A}$ & & $M B E$ & \\
\hline & Exp.Sign & (1) & & $-(2)$ & & (3) & \\
\hline Obfu(Present) & - & $\begin{array}{r}-0.0001 \\
(-1.38)\end{array}$ & & $\begin{array}{r}-0.0001 \\
(-1.10)\end{array}$ & & $\begin{array}{r}-0.0001 \\
(-1.22)\end{array}$ & \\
\hline Obfu(Response) & - & $\begin{array}{r}-0.0001 \\
(-2.61)\end{array}$ & $* * *$ & $\begin{array}{r}-0.0001 \\
(-1.09)\end{array}$ & & $\begin{array}{r}-0.0001 \\
(-2.45)\end{array}$ & $* *$ \\
\hline Info(Both) & + & $\begin{array}{r}0.0002 \\
(2.16)\end{array}$ & $* *$ & $\begin{array}{r}0.0001 \\
(0.65)\end{array}$ & & $\begin{array}{r}0.0002 \\
(1.56)\end{array}$ & \\
\hline Obfu(Present) ${ }^{*} E M$ & - & & & $\begin{array}{l}0.0000 \\
(-0.52)\end{array}$ & & $\begin{array}{r}-0.0002 \\
(-1.55)\end{array}$ & \\
\hline Obfu(Response $) * E M$ & - & & & $\begin{array}{r}-0.0002 \\
(-1.56)\end{array}$ & & $\begin{array}{r}0.0000 \\
(0.39)\end{array}$ & \\
\hline Info $($ Both $) * E M$ & + & & & $\begin{array}{r}0.0004 \\
(1.94)\end{array}$ & $*$ & $\begin{array}{r}0.0004 \\
(2.54)\end{array}$ & $* *$ \\
\hline$I I \_D A$ & & & & $\begin{array}{r}-0.0001 \\
(-0.64)\end{array}$ & & & \\
\hline$M B E$ & & & & & & $\begin{array}{r}0.0001 \\
(0.82)\end{array}$ & \\
\hline UESURP & & $\begin{array}{r}-0.0492 \\
(-6.93)\end{array}$ & $* * *$ & $\begin{array}{r}-0.0495 \\
(-7.12)\end{array}$ & $* * *$ & $\begin{array}{r}-0.0490 \\
(-7.01)\end{array}$ & $* * *$ \\
\hline AFSTD & & $\begin{array}{r}0.0645 \\
(4.16)\end{array}$ & $* * *$ & $\begin{array}{r}0.0638 \\
(4.09)\end{array}$ & $* * *$ & $\begin{array}{r}0.0646 \\
(4.14)\end{array}$ & $* * *$ \\
\hline$C A R$ & & $\begin{array}{r}-0.0041 \\
(-2.61)\end{array}$ & $* * *$ & $\begin{array}{r}-0.0043 \\
(-2.90)\end{array}$ & $* * *$ & $\begin{array}{r}-0.0043 \\
(-2.93)\end{array}$ & $* * *$ \\
\hline$\triangle L E P S$ & & $\begin{array}{r}0.0170 \\
(1.56)\end{array}$ & & $\begin{array}{r}0.0191 \\
(1.74)\end{array}$ & $*$ & $\begin{array}{r}0.0190 \\
(1.72)\end{array}$ & $*$ \\
\hline RET & & $\begin{array}{r}0.0001 \\
(0.21)\end{array}$ & & $\begin{array}{r}0.0000 \\
(0.05)\end{array}$ & & $\begin{array}{r}0.0000 \\
(0.06)\end{array}$ & \\
\hline SIZE & & $\begin{array}{r}0.0001 \\
(0.95)\end{array}$ & & $\begin{array}{r}0.0000 \\
(0.65)\end{array}$ & & $\begin{array}{r}0.0001 \\
(0.73)\end{array}$ & \\
\hline$L M B$ & & $\begin{array}{r}-0.0001 \\
(-0.13)\end{array}$ & & $\begin{array}{r}0.0001 \\
(0.28)\end{array}$ & & $\begin{array}{r}0.0001 \\
(0.25)\end{array}$ & \\
\hline$A F N$ & & $\begin{array}{l}0.0000 \\
(-4.62)\end{array}$ & $* * *$ & $\begin{array}{l}0.0000 \\
(-4.30)\end{array}$ & $* * *$ & $\begin{array}{l}0.0000 \\
(-4.29)\end{array}$ & $* * *$ \\
\hline INST_OWN & & $\begin{array}{r}-0.0002 \\
(-0.40)\end{array}$ & & $\begin{array}{l}0.0000 \\
(-0.03)\end{array}$ & & $\begin{array}{r}-0.0001 \\
(-0.13)\end{array}$ & \\
\hline LOSS & & $\begin{array}{r}0.0002 \\
(0.51)\end{array}$ & & $\begin{array}{r}0.0003 \\
(1.05)\end{array}$ & & $\begin{array}{r}0.0003 \\
(0.99)\end{array}$ & \\
\hline$R \& D$ & & $\begin{array}{r}-0.0005 \\
(-1.24)\end{array}$ & & $\begin{array}{r}-0.0005 \\
(-1.21)\end{array}$ & & $\begin{array}{r}-0.0005 \\
(-1.31)\end{array}$ & \\
\hline FWDLOOK(Present) & & $\begin{array}{l}0.0000 \\
(-0.66)\end{array}$ & & $\begin{array}{l}0.0000 \\
(-0.19)\end{array}$ & & $\begin{array}{l}0.0000 \\
(-0.11)\end{array}$ & \\
\hline FWDLOOK(Response) & & $\begin{array}{r}-0.0001 \\
(-0.96)\end{array}$ & & $\begin{array}{r}-0.0001 \\
(-0.97)\end{array}$ & & $\begin{array}{r}-0.0001 \\
(-0.99)\end{array}$ & \\
\hline POSTONE(Present) & & $\begin{array}{l}0.0000 \\
(-0.94)\end{array}$ & & $\begin{array}{l}0.0000 \\
(-0.70)\end{array}$ & & $\begin{array}{l}0.0000 \\
(-0.80)\end{array}$ & \\
\hline POSTONE(Response) & & $\begin{array}{r}0.0000 \\
(0.90)\end{array}$ & & $\begin{array}{r}0.0000 \\
(0.45)\end{array}$ & & $\begin{array}{r}0.0000 \\
(0.57)\end{array}$ & \\
\hline NEGTONE(Present) & & $\begin{array}{r}-0.0001 \\
(-2.49)\end{array}$ & $* *$ & $\begin{array}{r}-0.0001 \\
(-2.93)\end{array}$ & $* * *$ & $\begin{array}{r}-0.0001 \\
(-2.96)\end{array}$ & $* * *$ \\
\hline NEGTONE(Response) & & $\begin{array}{r}0.0000 \\
(0.03)\end{array}$ & & $\begin{array}{r}0.0000 \\
(0.17)\end{array}$ & & $\begin{array}{r}0.0000 \\
(0.20)\end{array}$ & \\
\hline GUIDANCE & & $\begin{array}{r}-0.0003 \\
(-1.56)\end{array}$ & & $\begin{array}{r}-0.0003 \\
(-1.99)\end{array}$ & $* *$ & $\begin{array}{r}-0.0003 \\
(-1.98)\end{array}$ & $* *$ \\
\hline Firm FE & & YES & & YES & & YES & \\
\hline $\begin{array}{l}\text { No. Obs. } \\
\text { Adj R2 }\end{array}$ & & $\begin{array}{r}29,656 \\
3.514 \%\end{array}$ & & $\begin{array}{r}29,656 \\
4.555 \%\end{array}$ & & $\begin{array}{l}29,656 \\
4.675 \%\end{array}$ & \\
\hline
\end{tabular}

Notes: Table 7 presents results from estimating the relation between the change in analyst forecast accuracy and the latent components of linguistic complexity. All the variables are as defined in Appendix. $t$-statistics appear in parentheses and are based on standard errors clustered by firm and disclosure date of the conference call. $* * *, * *$, and $*$ denote statistical significance at the $0.01,0.05$, and 0.10 levels (two-tail), respectively. 
Table 8

Linguistic Complexity and Analyst Forecast Accuracy and Dispersion

Panel B: Linguistic Complexity and Analyst Forecast Dispersion

\begin{tabular}{|c|c|c|c|c|c|c|c|}
\hline \multirow{3}{*}{$\begin{array}{l}\text { Interaction terms } \\
\text { Variable }\end{array}$} & \multirow[b]{3}{*}{ Exp.Sign } & \multicolumn{6}{|c|}{ Dependent Variable $=\Delta \mathrm{AF}$ DISP } \\
\hline & & & & II_DA & & MBE & \\
\hline & & $(1)$ & & $(2)$ & & (3) & \\
\hline Obfu(Present) & + & $\begin{array}{r}0.0014 \\
(1.89)\end{array}$ & $*$ & $\begin{array}{r}0.0004 \\
(0.44)\end{array}$ & & $\begin{array}{r}0.0016 \\
(1.97)\end{array}$ & $* *$ \\
\hline Obfu(Response) & + & $\begin{array}{r}0.0015 \\
(2.19)\end{array}$ & $* *$ & $\begin{array}{r}0.0016 \\
(1.92)\end{array}$ & $*$ & $\begin{array}{r}\mathbf{0 . 0 0 1 3} \\
(1.75)\end{array}$ & $*$ \\
\hline Info(Both) & - & $\begin{array}{r}-0.0031 \\
(-2.41)\end{array}$ & $* *$ & $\begin{array}{r}-0.0013 \\
(-0.90)\end{array}$ & & $\begin{array}{r}-0.0026 \\
(-1.90)\end{array}$ & $*$ \\
\hline Obfu(Present) $*$ EM & + & & & $\begin{array}{r}0.0028 \\
(2.21)\end{array}$ & $* *$ & $\begin{array}{r}-0.0018 \\
(-1.53)\end{array}$ & \\
\hline Obfu(Response $) * E M$ & + & & & $\begin{array}{l}0.0000 \\
(-0.02)\end{array}$ & & $\begin{array}{r}0.0025 \\
(1.91)\end{array}$ & $*$ \\
\hline Info $($ Both $) * E M$ & - & & & $\begin{array}{r}-0.0052 \\
(-1.89)\end{array}$ & $*$ & $\begin{array}{r}-0.0054 \\
(-2.38)\end{array}$ & $* *$ \\
\hline II_DA & & & & $\begin{array}{r}0.0024 \\
(1.11)\end{array}$ & & & \\
\hline$M B E$ & & & & & & $\begin{array}{r}-0.0019 \\
(-0.93)\end{array}$ & \\
\hline UESURP & & $\begin{array}{r}0.0075 \\
(0.10)\end{array}$ & & $\begin{array}{r}0.014 \\
(0.18)\end{array}$ & & $\begin{array}{l}0.007 \\
(0.10)\end{array}$ & \\
\hline$C A R$ & & $\begin{array}{r}0.0025 \\
(0.15)\end{array}$ & & $\begin{array}{r}0.0034 \\
(0.21)\end{array}$ & & $\begin{array}{r}0.0024 \\
(0.15)\end{array}$ & \\
\hline$\triangle L E P S$ & & $\begin{array}{r}0.2540 \\
(2.14)\end{array}$ & $* *$ & $\begin{array}{r}0.2417 \\
(2.06)\end{array}$ & $* *$ & $\begin{array}{r}0.2534 \\
(2.14)\end{array}$ & $* *$ \\
\hline$R E T$ & & $\begin{array}{r}0.0008 \\
(0.25)\end{array}$ & & $\begin{array}{r}0.0007 \\
(0.20)\end{array}$ & & $\begin{array}{r}0.0008 \\
(0.25)\end{array}$ & \\
\hline SIZE & & $\begin{array}{r}0.0005 \\
(0.53)\end{array}$ & & $\begin{array}{r}0.0005 \\
(0.58)\end{array}$ & & $\begin{array}{r}0.0005 \\
(0.50)\end{array}$ & \\
\hline$B M$ & & $\begin{array}{r}0.0102 \\
(2.21)\end{array}$ & $* *$ & $\begin{array}{r}0.0096 \\
(2.07)\end{array}$ & $* *$ & $\begin{array}{r}0.0101 \\
(2.18)\end{array}$ & $* *$ \\
\hline$A F N$ & & $\begin{array}{r}0.0002 \\
(2.33)\end{array}$ & $* *$ & $\begin{array}{r}0.0002 \\
(2.19)\end{array}$ & $* *$ & $\begin{array}{r}0.0002 \\
(2.33)\end{array}$ & $* *$ \\
\hline INST_OWN & & $\begin{array}{r}0.0043 \\
(0.72)\end{array}$ & & $\begin{array}{r}0.0039 \\
(0.66)\end{array}$ & & $\begin{array}{r}0.0042 \\
(0.71)\end{array}$ & \\
\hline LOSS & & $\begin{array}{r}0.0108 \\
(2.49)\end{array}$ & $* *$ & $\begin{array}{r}0.0100 \\
(2.33)\end{array}$ & $* *$ & $\begin{array}{r}0.0107 \\
(2.46)\end{array}$ & $* *$ \\
\hline$R \& D$ & & $\begin{array}{r}0.0110 \\
(2.22)\end{array}$ & $* *$ & $\begin{array}{r}0.0110 \\
(2.27)\end{array}$ & $* *$ & $\begin{array}{r}0.0112 \\
(2.26)\end{array}$ & $* *$ \\
\hline FWDLOOK(Present) & & $\begin{array}{r}-0.0001 \\
(-0.31)\end{array}$ & & $\begin{array}{r}-0.0003 \\
(-0.54)\end{array}$ & & $\begin{array}{r}-0.0002 \\
(-0.33)\end{array}$ & \\
\hline FWDLOOK(Response) & & $\begin{array}{r}0.0001 \\
(0.16)\end{array}$ & & $\begin{array}{r}0.0001 \\
(0.09)\end{array}$ & & $\begin{array}{r}0.0001 \\
(0.15)\end{array}$ & \\
\hline POSTONE(Present) & & $\begin{array}{r}-0.0001 \\
(-0.13)\end{array}$ & & $\begin{array}{r}-0.0001 \\
(-0.17)\end{array}$ & & $\begin{array}{r}-0.0001 \\
(-0.15)\end{array}$ & \\
\hline POSTONE(Response) & & $\begin{array}{r}-0.0008 \\
(-1.23)\end{array}$ & & $\begin{array}{r}-0.0007 \\
(-1.06)\end{array}$ & & $\begin{array}{r}-0.0008 \\
(-1.22)\end{array}$ & \\
\hline NEGTONE(Present) & & $\begin{array}{r}0.0010 \\
(1.92)\end{array}$ & $*$ & $\begin{array}{r}0.0010 \\
(2.03)\end{array}$ & $* *$ & $\begin{array}{r}0.0010 \\
(1.95)\end{array}$ & $*$ \\
\hline NEGTONE(Response) & & $\begin{array}{r}0.0004 \\
(0.46)\end{array}$ & & $\begin{array}{r}0.0004 \\
(0.53)\end{array}$ & & $\begin{array}{r}0.0004 \\
(0.48)\end{array}$ & \\
\hline GUIDANCE & & $\begin{array}{r}0.0108 \\
(4.43)\end{array}$ & $* * *$ & $\begin{array}{r}0.0110 \\
(4.53)\end{array}$ & $* * *$ & $\begin{array}{r}0.0108 \\
(4.43)\end{array}$ & $* * *$ \\
\hline Firm FE & & YES & & YES & & YES & \\
\hline $\begin{array}{l}\text { No. Obs. } \\
\text { Adj R2 }\end{array}$ & & $\begin{array}{r}21,224 \\
1.469 \% \\
\end{array}$ & & $\begin{array}{r}21,224 \\
1.225 \% \\
\end{array}$ & & $\begin{array}{r}21,224 \\
1.485 \% \\
\end{array}$ & \\
\hline
\end{tabular}

Notes: Table 8 presents results from estimating the relation between the change in analyst forecast dispersion and the latent components of linguistic complexity. All the variables are as defined in Appendix. $t$-statistics appear in parentheses and are based on standard errors clustered by firm and disclosure date of the conference call. ***, $* *$, and $*$ denote statistical significance at the $0.01,0.05$, and 0.10 levels (two-tail), respectively. 
Table 9

\section{Linguistic Complexity and Changes in Institutional Ownership}

Panel A: Changes in Institutional Ownership and Linguistic Complexity

\begin{tabular}{|c|c|c|c|c|c|c|c|}
\hline \multirow{3}{*}{$\begin{array}{l}\text { Interaction terms } \\
\text { Variable }\end{array}$} & & \multicolumn{6}{|c|}{ Dependent Variable $=\Delta$ INST_OWN } \\
\hline & & & & II_DA & & $M B E$ & \\
\hline & Exp.Sign & (1) & & (2) & & (3) & \\
\hline Obfu(Present) & - & $\begin{array}{r}-0.0010 \\
(-2.01)\end{array}$ & $* *$ & $\begin{array}{r}-0.0007 \\
(-1.11)\end{array}$ & & $\begin{array}{r}-0.0008 \\
(-1.47)\end{array}$ & \\
\hline Obfu(Response) & - & $\begin{array}{r}-0.0006 \\
(-1.26)\end{array}$ & & $\begin{array}{r}-0.0003 \\
(-0.59)\end{array}$ & & $\begin{array}{r}-0.0006 \\
(-1.24)\end{array}$ & \\
\hline Info(Both) & + & $\begin{array}{r}0.0031 \\
(4.05)\end{array}$ & $* * *$ & $\begin{array}{r}0.0024 \\
(2.62)\end{array}$ & $* * *$ & $\begin{array}{r}0.0033 \\
(4.13)\end{array}$ & $* * *$ \\
\hline Obfu(Present) ${ }^{*} E M$ & - & & & $\begin{array}{r}-0.0010 \\
(-1.01)\end{array}$ & & $\begin{array}{r}-0.0022 \\
(-1.69)\end{array}$ & $*$ \\
\hline Obfu(Response) $* E M$ & - & & & $\begin{array}{r}-0.0007 \\
(-0.78)\end{array}$ & & $\begin{array}{r}0.0002 \\
(0.18)\end{array}$ & \\
\hline $\operatorname{Info}($ Both $) * E M$ & + & & & $\begin{array}{r}0.0019 \\
(1.19)\end{array}$ & & $\begin{array}{r}-0.0019 \\
(-0.82)\end{array}$ & \\
\hline$I I \_D A$ & & & & $\begin{array}{l}-0.002 \\
(-1.66)\end{array}$ & $*$ & & \\
\hline$M B E$ & & & & & & $\begin{array}{r}-0.0011 \\
(-0.57)\end{array}$ & \\
\hline$A F \_R E V$ & & $\begin{array}{r}0.1739 \\
(3.17)\end{array}$ & $* * *$ & $\begin{array}{r}0.1731 \\
(3.16)\end{array}$ & $* * *$ & $\begin{array}{r}0.1740 \\
(3.18)\end{array}$ & $* * *$ \\
\hline POST_CAR & & $\begin{array}{r}0.0279 \\
(6.10)\end{array}$ & $* * *$ & $\begin{array}{r}0.028 \\
(6.05)\end{array}$ & $* * *$ & $\begin{array}{r}0.0279 \\
(6.11)\end{array}$ & $* * *$ \\
\hline UESURP & & $\begin{array}{r}0.1301 \\
(4.72)\end{array}$ & $* * *$ & $\begin{array}{l}0.131 \\
(4.74)\end{array}$ & $* * *$ & $\begin{array}{r}0.1301 \\
(4.72)\end{array}$ & $* * *$ \\
\hline AFSTD & & $\begin{array}{r}-0.1226 \\
(-2.28)\end{array}$ & $* *$ & $\begin{array}{r}-0.1227 \\
(-2.28)\end{array}$ & $* *$ & $\begin{array}{r}-0.1240 \\
(-2.3)\end{array}$ & $* *$ \\
\hline$C A R$ & & $\begin{array}{r}0.0391 \\
(4.08)\end{array}$ & $* * *$ & $\begin{array}{r}0.0390 \\
(4.05)\end{array}$ & $* * *$ & $\begin{array}{r}0.0391 \\
(4.08)\end{array}$ & $* * *$ \\
\hline$\triangle L E P S$ & & $\begin{array}{r}0.1410 \\
(3.14)\end{array}$ & $* * *$ & $\begin{array}{r}0.1433 \\
(3.19)\end{array}$ & $* * *$ & $\begin{array}{r}0.1410 \\
(3.14)\end{array}$ & $* * *$ \\
\hline$R E T$ & & $\begin{array}{r}0.0048 \\
(2.46)\end{array}$ & $* *$ & $\begin{array}{r}0.0049 \\
(2.45)\end{array}$ & $* *$ & $\begin{array}{r}0.0049 \\
(2.5)\end{array}$ & $* *$ \\
\hline SIZE & & $\begin{array}{r}-0.0017 \\
(-2.9)\end{array}$ & $* * *$ & $\begin{array}{r}-0.0017 \\
(-2.83)\end{array}$ & $* * *$ & $\begin{array}{r}-0.0017 \\
(-2.93)\end{array}$ & $* * *$ \\
\hline$B M$ & & $\begin{array}{r}-0.0039 \\
(-1.24)\end{array}$ & & $\begin{array}{r}-0.0035 \\
(-1.12)\end{array}$ & & $\begin{array}{r}-0.0039 \\
(-1.27)\end{array}$ & \\
\hline$A F N$ & & $\begin{array}{r}0.0003 \\
(4.3)\end{array}$ & $* * *$ & $\begin{array}{r}0.0003 \\
(4.33)\end{array}$ & $* * *$ & $\begin{array}{r}0.0003 \\
(4.31)\end{array}$ & $* * *$ \\
\hline$L E V$ & & $\begin{array}{r}0.0031 \\
(0.74)\end{array}$ & & $\begin{array}{r}0.0031 \\
(0.74)\end{array}$ & & $\begin{array}{r}0.0030 \\
(0.71)\end{array}$ & \\
\hline EPRATIO & & $\begin{array}{r}0.0131 \\
(1.48)\end{array}$ & & $\begin{array}{r}0.0138 \\
(1.55)\end{array}$ & & $\begin{array}{r}0.0131 \\
(1.48)\end{array}$ & \\
\hline FWDLOOK(Present) & & $\begin{array}{r}-0.0003 \\
(-1.00)\end{array}$ & & $\begin{array}{r}-0.0003 \\
(-0.95)\end{array}$ & & $\begin{array}{r}-0.0003 \\
(-1.00)\end{array}$ & \\
\hline FWDLOOK(Response) & & $\begin{array}{r}0.0025 \\
(4.95)\end{array}$ & $* * *$ & $\begin{array}{r}0.0025 \\
(4.98)\end{array}$ & $* * *$ & $\begin{array}{r}0.0025 \\
(4.94)\end{array}$ & $* * *$ \\
\hline POSTONE(Present) & & $\begin{array}{r}-0.0004 \\
(-1.53)\end{array}$ & & $\begin{array}{r}-0.0004 \\
(-1.52)\end{array}$ & & $\begin{array}{r}-0.0004 \\
(-1.54)\end{array}$ & \\
\hline POSTONE(Response) & & $\begin{array}{r}0.0020 \\
(5.00)\end{array}$ & $* * *$ & $\begin{array}{r}0.0019 \\
(4.90)\end{array}$ & $* * *$ & $\begin{array}{r}0.0020 \\
(5.00)\end{array}$ & $* * *$ \\
\hline NEGTONE(Present) & & $\begin{array}{r}0.0001 \\
(0.46)\end{array}$ & & $\begin{array}{r}0.0001 \\
(0.41)\end{array}$ & & $\begin{array}{r}0.0001 \\
(0.47)\end{array}$ & \\
\hline NEGTONE(Response) & & $\begin{array}{r}-0.0003 \\
(-0.73)\end{array}$ & & $\begin{array}{r}0.000 \\
(-0.76)\end{array}$ & & $\begin{array}{r}-0.0003 \\
(-0.72)\end{array}$ & \\
\hline GUIDANCE & & $\begin{array}{r}-0.0001 \\
(-0.08)\end{array}$ & & $\begin{array}{r}0.000 \\
(-0.06)\end{array}$ & & $\begin{array}{r}-0.0001 \\
(-0.07)\end{array}$ & \\
\hline Firm FE & & YES & & YES & & YES & \\
\hline $\begin{array}{l}\text { No. Obs. } \\
\text { Adj R2 }\end{array}$ & & $\begin{array}{r}27,233 \\
2.77 \% \\
\end{array}$ & & $\begin{array}{l}27,233 \\
2.80 \% \\
\end{array}$ & & $\begin{array}{r}27,233 \\
2.783 \% \\
\end{array}$ & \\
\hline
\end{tabular}


Table 9

\section{Linguistic Complexity and Changes in Institutional Ownership}

Panel B: Changes in Institutional Ownership and Linguistic Complexity for TRA vs. QIX vs. DED

\begin{tabular}{|c|c|c|c|c|c|c|c|}
\hline \multirow{3}{*}{$\begin{array}{l}\text { Interaction terms } \\
\text { Variable }\end{array}$} & \multirow[b]{3}{*}{ Exp.Sign } & \multicolumn{6}{|c|}{ Dependent Variable $=\Delta$ INST_TRA_QIX_DED } \\
\hline & & \multirow{2}{*}{\multicolumn{2}{|c|}{$\begin{array}{c}\boldsymbol{T R} \boldsymbol{A} \\
(1)\end{array}$}} & \multirow{2}{*}{$\begin{array}{c}\boldsymbol{Q I X} \\
(2)\end{array}$} & \multirow{2}{*}{\multicolumn{3}{|c|}{$\begin{array}{c}\boldsymbol{D E D} \\
(3)\end{array}$}} \\
\hline & & & & & & & \\
\hline \multirow[t]{2}{*}{ Obfu(Present) } & - & $-\mathbf{0 . 0 0 0 7}$ & $* *$ & -0.0002 & & -0.0001 & \\
\hline & & $(-2.00)$ & & $(-0.66)$ & & $(-0.69)$ & \\
\hline \multirow[t]{2}{*}{ Obfu(Response) } & - & -0.0007 & $* *$ & 0.0000 & & -0.0002 & \\
\hline & & $(-2.05)$ & & $(-0.09)$ & & $(-1.21)$ & \\
\hline \multirow[t]{2}{*}{ Info(Both) } & + & 0.0013 & $* *$ & 0.0009 & & 0.0003 & \\
\hline & & $(2.07)$ & & (1.62) & & $(0.96)$ & \\
\hline \multirow[t]{2}{*}{ UESURP } & & 0.1686 & $* * *$ & 0.0322 & & -0.0265 & \\
\hline & & $(8.99)$ & & $(1.35)$ & & $(-1.45)$ & \\
\hline \multirow[t]{2}{*}{$A F S T D$} & & -0.0280 & & -0.1266 & $* * *$ & 0.0023 & \\
\hline & & $(-0.77)$ & & $(-2.98)$ & & $(0.09)$ & \\
\hline \multirow[t]{2}{*}{$C A R$} & & 0.0506 & $* * *$ & -0.0058 & & -0.0204 & $* * *$ \\
\hline & & $(6.58)$ & & $(-0.85)$ & & $(-5.81)$ & \\
\hline \multirow{2}{*}{$\triangle L E P S$} & & 0.1564 & $* * *$ & 0.0434 & & -0.0487 & $* *$ \\
\hline & & $(4.84)$ & & $(1.23)$ & & $(-2.14)$ & \\
\hline \multirow[t]{2}{*}{$R E T$} & & -0.0014 & & 0.0074 & $* * *$ & -0.0026 & $* * *$ \\
\hline & & $(-0.97)$ & & $(5.36)$ & & $(-3.34)$ & \\
\hline \multirow[t]{2}{*}{ SIZE } & & -0.0003 & & -0.0012 & $* * *$ & -0.0004 & $* *$ \\
\hline & & $(-0.83)$ & & $(-3.21)$ & & $(-2.14)$ & \\
\hline \multirow[t]{2}{*}{$B M$} & & 0.0119 & $* * *$ & -0.0158 & $* *$ & -0.0001 & \\
\hline & & $(5.49)$ & & $(-7.76)$ & & $(-0.09)$ & \\
\hline \multirow[t]{2}{*}{$A F N$} & & 0.0001 & $* * *$ & 0.0001 & & 0.0001 & $* * *$ \\
\hline & & $(2.95)$ & & $(2.04)$ & & (2.94) & \\
\hline \multirow[t]{2}{*}{$L E V$} & & 0.0056 & $*$ & 0.0002 & & -0.0052 & $* * *$ \\
\hline & & $(1.85)$ & & $(0.05)$ & & $(-2.60)$ & \\
\hline \multirow[t]{2}{*}{ EPRATIO } & & 0.0039 & & 0.0166 & & 0.0018 & \\
\hline & & $(0.55)$ & & $(1.22)$ & & $(0.12)$ & \\
\hline \multirow[t]{2}{*}{ FWDLOOK(Present) } & & -0.0002 & & 0.0000 & & 0.0000 & \\
\hline & & $(-0.94)$ & & $(-0.18)$ & & $(0.58)$ & \\
\hline \multirow[t]{2}{*}{ FWDLOOK(Response) } & & 0.0026 & $* * *$ & 0.0007 & $* *$ & -0.0003 & * \\
\hline & & (7.49) & & $(2.02)$ & & $(-1.92)$ & \\
\hline \multirow[t]{2}{*}{ POSTONE(Present) } & & -0.0002 & & 0.0000 & & 0.0000 & \\
\hline & & $(-0.91)$ & & $(0.07)$ & & $(0.22)$ & \\
\hline POSTONE(Response) & & 0.0014 & $* * *$ & 0.0007 & $* * *$ & 0.0000 & \\
\hline & & $(5.12)$ & & $(2.88)$ & & $(0.02)$ & \\
\hline NEGTONE(Present) & & 0.0000 & & 0.0001 & & -0.0001 & \\
\hline & & $(0.03)$ & & $(0.78)$ & & $(-0.67)$ & \\
\hline NEGTONE(Response) & & -0.0004 & & 0.0000 & & 0.0002 & \\
\hline & & $(-1.24)$ & & $(0.13)$ & & $(1.30)$ & \\
\hline GUIDANCE & & 0.0011 & & -0.0013 & & 0.0000 & \\
\hline & & $(1.12)$ & & $(-1.39)$ & & $(0.01)$ & \\
\hline Firm FE & & YES & & YES & & YES & \\
\hline No. Obs. & & 27,395 & & 27,641 & & 18,099 & \\
\hline Adj R2 & & $2.994 \%$ & & $1.538 \%$ & & $1.147 \%$ & \\
\hline
\end{tabular}

Notes: Table 9 presents results from estimating the relation between the changes in institutional ownership and the latent components of linguistic complexity. All the variables are as defined in Appendix. $t$-statistics appear in parentheses and are based on standard errors clustered by firm and disclosure date of the conference call. ***,**, and * denote statistical significance at the $0.01,0.05$, and 0.10 levels (two-tail), respectively. 